\title{
개발도상국 여성의 건강불평등 현황과 원인, 윤리적 이슈 및 해결책 고찰
}

이상미 (KOICA ODA연구정보센터 과장,

서울대학교 보건대학원 보건정책관리학 박사과정)

고브니엘 (서울대학교 보건대학원 보건정책관리학 석사)

김수지 (서울대학교 보건대학원 보건정책관리학 석사과정)

김수진 (서울대학교 보건대학원 보건정책관리학 석사과정)

김한솔 (서울대학교 치의학과 학사과정)

목 차

I. 현황조사

1. 남녀 성비와 젠더불평등지수

2. 질병부담(Global Burden of Disease)

II. 원인 분석(Root Cause Analysis)

1. 개발도상국 여성의 건강불평등 원인

2. $\mathrm{HIV}$ 를 제외한 성매개질환

3. 알츠하이머

4. 우울증

III. 윤리적 이슈(Ethical Issue)

\section{1. 질병별 접근}

2. 연구 수행 과정에서의 접근

IV. 문제 해결을 위한 제안(Problem Solving)

참고 문헌 


\section{요 약}

개발도상국 여성의 건강불평등을 잘 이해하기 위해서는 데이터에 기반을 두고 현황을 정확하게 이해하는 것이 중요하다. 동 연구에서는 지역별 · 국가별 · 성별에 따른 질병부담 (Global burden of disease)을 살펴봄으로써 어떠한 질병에서 질병부담이 높은지, 성별 에 따른 질병부담의 차이가 가장 큰 질병은 무엇인지, 여성의 질병부담이 높은 질병은 무엇인지 분석하고자 한다.

또한 개발도상국 여성의 건강불평등 원인과 특정 질환에서, Ishikawa의 Fishbone Diagram을 이용해 여성의 질병부담이 높게 나타나는 원인을 분석했다. 


\section{I . 현황조사}

먼저, 개발도상국 여성의 건강불평등 현황을 파악하기 위해, $\triangle$ 전 세계 남녀 성비와 $\triangle$ 젠더

불평등지수 그리고 $\triangle$ 개별 질병의 질병부담(Global Burden of Disease)을 살펴보고자 한다.

\section{제II장}

섹

\section{1. 남녀 성비와 젠더불평등지수}

2015년 기준, 전 세계 인구 중 49.55\%가 여성이며 또 인구 중 여성의 비율은 국가별로 상이하다 (<그림 $1>$ 참고. 색이 진할수록 여성 성비가 낮음을 의미). 이중 중국, 인도, 파키스탄, 아프가니스탄, 이집트, 나이지리아 등의 국가에서는 인구 중 여성의 비율이 $24.8 \sim 49.4 \%$ 이며, 이는 전 세계 평균보다 낮은 수치다.

\section{〈그림 1〉성비(sex ratio)}

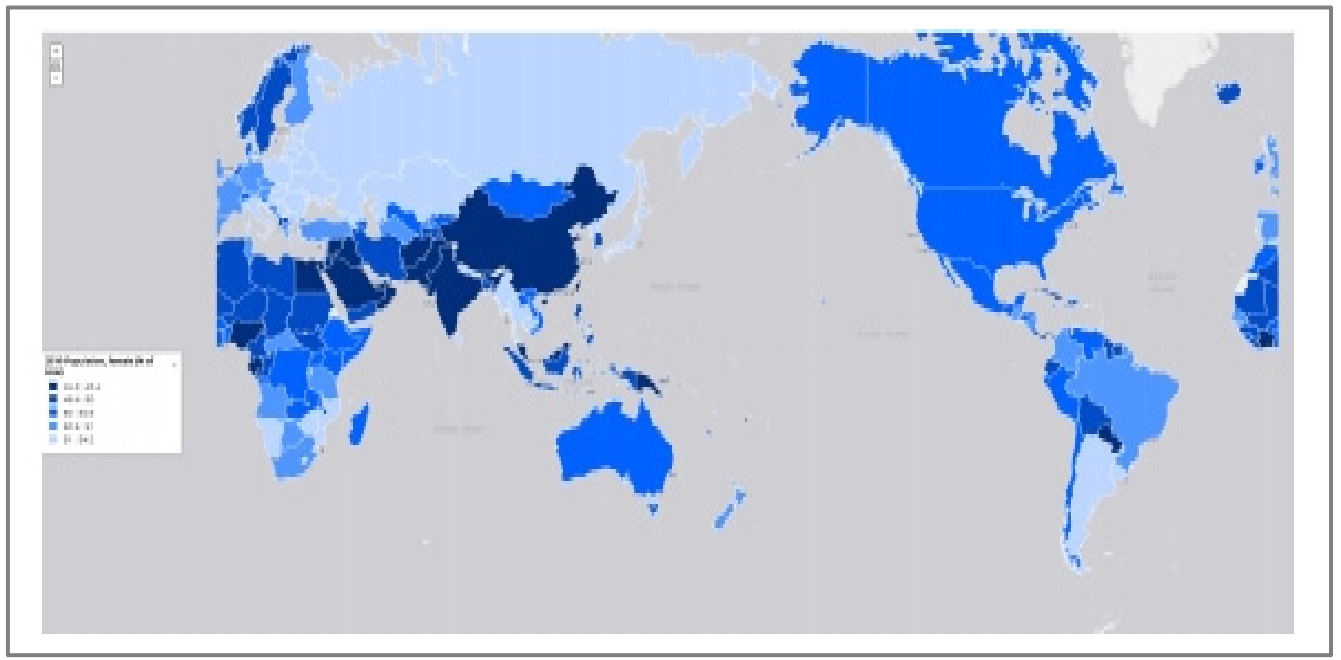

출처 : QUARTZ 홈페이지1)

유엔개발계획(United Nations Development Programme, 이하 UNDP)이 발표하는 젠더 불평등지수2)와 함께 살펴보면(<그림 2> 참고, 색이 진할수록 젠더불평등지수가 높음을 의미), 젠더불평등지수가 낮은 국가와 여성의 인구 성비가 낮은 국가가 유사하다는 것을 확인할 수 있다.

1) https://qz.com/335183/heres-why-men-on-earth-outnumber-women-by-60-million(접속일: 2018.06.30.)

2) 젠더불평등지수 : 젠더불평등지수는 생식 건강, 권한, 노동시장 세 영역을 고려한 지수다. 이는 건강, 교육, 사회·경제적 수준을 계산에 포함하며, 다양한 층위의 젠더 불평등의 확인을 용이하게 한다. 


\section{〈그림 2〉 젠더불평등지수(gender inequality index)}

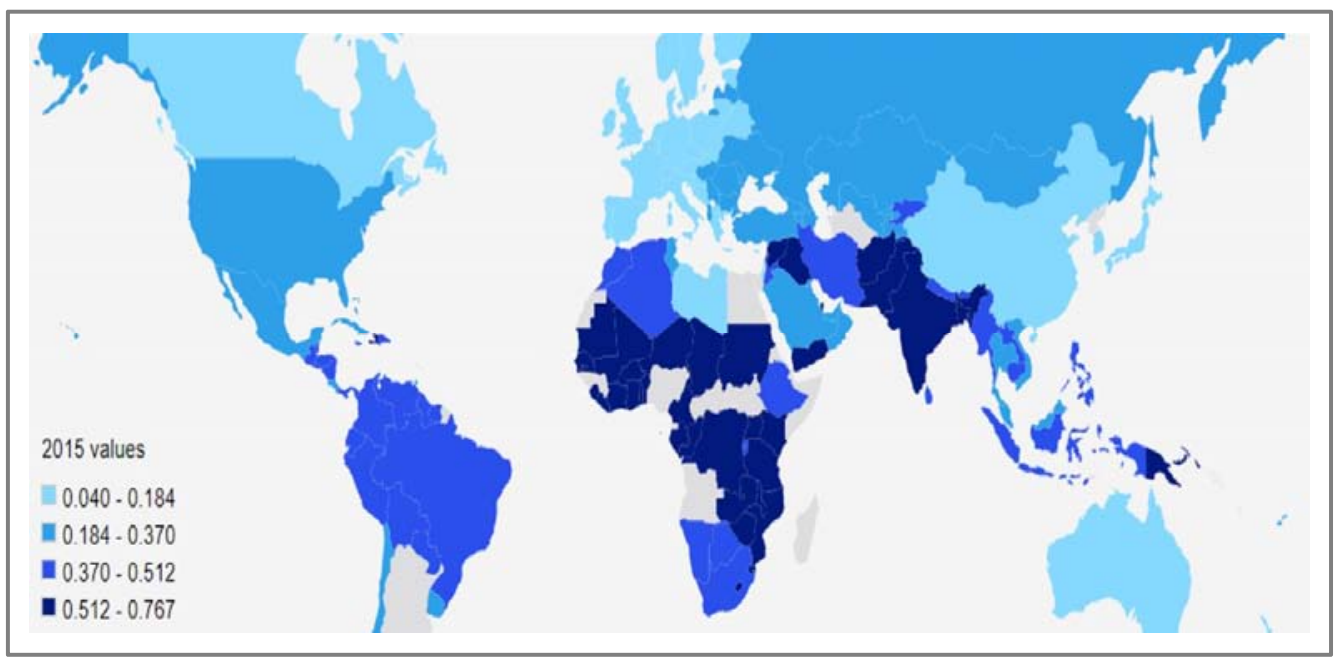

출처: UNDP (2017) "Human Development Reports"

\section{2. 질병부담(Global Burden of Disease)}

질병부담지표 중 가장 대표적인 지표는 DALY(Disability- Adjusted Life Year)3)이다. DALY는 세계보건기구(World Health Organization, 이하 WHO)가 제안한 지표로, 해당 질병으로 인한 장애 혹은 사망 등의 건강 손실을 연수(years)로 표현한 지표다. 동 연구에서는 국가별·성별로 구분해 개별 질병의 DALY를 분석하는 방법으로 여성의 건강 현황을 보다 구체적으로 살펴보고자 한다.4)

\section{1) 질병부담(DALY)이 높은 질병은?}

전 세계의 질병은 전염성 질환(communicable disease), 비전염성질환(non-communicable disease), 부상(injury)으로 구분할 수 있다. 이 3개 범주에서 여성 DALY 절대량이 높은 질병(남성과의 비교가 아닌)을 각각 상위 3 6개씩 정리하면 아래 <표 $1>$ 과 같다.

3) $\mathrm{DALYi}=\mathrm{YLLi}+\mathrm{YLDi}$ 이며, YLL(Years of Life Lost)은 조기 사망으로 인한 환자가 잃은 연수이며, YLD(Years Lost due to Disability)는 질병으로 인해 생긴 장애로 잃은 연수를 의미한다.

4) DALY 데이터 출처는 http://ghdx.healthdata.org/gbd-2016 이다. (접속일: 2018.06.30.) 
〈표 1〉2016년 여성 DALY 기준, Top 3 6 질병

\begin{tabular}{|c|c|c|c|c|}
\hline \multirow{2}{*}{\multicolumn{2}{|c|}{ 질병 }} & \multicolumn{2}{|c|}{ 성별 } & \multirow{3}{*}{$\begin{array}{l}\text { 차이(여성-남성) } \\
-8,582,194.90\end{array}$} \\
\hline & & \multirow{2}{*}{\begin{tabular}{c|} 
남성 \\
$50,213,405.56$
\end{tabular}} & \multirow{2}{*}{$\begin{array}{c}\text { 여성 } \\
41,631,210.65\end{array}$} & \\
\hline \multirow{5}{*}{$\begin{array}{l}\text { 전염성, } \\
\text { 신생아, } \\
\text { 영양 }\end{array}$} & Lower respiratory infections & & & \\
\hline & Diarrhea diseases & $38,107,803.64$ & $36,306,847.31$ & $-1,800,956.33$ \\
\hline & Malaria & $28,403,581.28$ & $27,797,651.30$ & $-605,929.98$ \\
\hline & Neonatal preterm birth & $35,010,441.62$ & $27,021,160.07$ & $-7,989,281.55$ \\
\hline & HIV/AIDS & $31,621,522.78$ & $25,953,868.91$ & $-5,667,653.87$ \\
\hline \multirow{5}{*}{ 비전염성 } & Ischemic heart disease & $106,822,641.76$ & $67,788,441.42$ & $-39,034,200.34$ \\
\hline & Stroke & $65,640,111.28$ & $50,805,024.39$ & $-14,835,086.90$ \\
\hline & Low back and neck pain & $38,406,784.04$ & $48,177,732.47$ & $9,770,948.44$ \\
\hline & Sense organ diseases & $32,537,549.12$ & $34,164,348.94$ & $1,626,799.82$ \\
\hline & $\begin{array}{l}\text { Chronic obstructive pulmonary } \\
\text { disease }\end{array}$ & $37,784,659.84$ & $25,649,651.68$ & $-12,135,008,16$ \\
\hline \multirow{3}{*}{ 부상 } & Road injuries & $54,163,450.29$ & $17,231,537.70$ & $-36,931,912.60$ \\
\hline & Falls & $21,335,246.02$ & $14,438,598.40$ & $-6,896,647,62$ \\
\hline & self-harm & $23,718,458.05$ & $11,431,140.98$ & $-12,287,317.07$ \\
\hline
\end{tabular}

출처: GHDx 홈페이지(http://ghdx.healthdata.org/gbd-2016) (접속일: 2018.06.30.) 내용을 바탕으로 저자가 재구성

전염성 질환에서는 하부 호흡기계 감염(Lower respiratory infections), 설사병(Diarrhea diseases), 말라리아(Malaria), 신생아 조산(Neonatal preterm birth), HIV/AIDS 순으로 부담 수가 높았다. 또한 비전염성 질환에서는 허혈성 심질환(Ischemic heart disease), 뇌졸중 (Stroke), 요통 및 목의 통증(Low back and neck pain), 감각기관 질환(Sense organ diseases), 만성폐쇄성 폐질환(Chronic obstructive pulmonary disease) 순이었다. 또 부상 은 길에서의 교통사고(Road injuries)가 가장 많았으며, 다음으로 낙상(Falls), 자해(Selfharm) 순이었다.

<표 1>을 통해 두 가지를 확인할 수 있었다. 첫째, 여성 DALY의 절대량이 높은 대부분의 질병에 대해 남성과 여성의 DALY를 비교해 보면, 남성의 DALY가 여성의 DALY보다 더 높았다는 점이다. 보통 남성보다 여성이 설사, 말라리아, HIV/AIDS 등의 주요 질병의 질병부 담이 높을 것으로 생각하지만 실제로는 그렇지 않다. 둘째, 여성이 남성에 비해 통계 집계 시 수치가 잘 포함되지 않는 한계가 있어 약 1 억 명의 여성이 DALY 계산 시 누락되었을 수 있다. 그럼에도 불구하고(Sen, 2003), 전체 DALY 중 여성의 DALY는 전체의 45\%를 차지한 다는 점을 확인할 수 있었다. 


\section{2) 남성과 여성의 질병부담(DALY) 차이가 큰 질병은?}

남녀의 DALY 차이가 큰 질병을 살펴보기 위해, 2016년 기준의 DALY를 성별로 나누어 분석했다. 남성에 비해 여성의 DALY가 높은 질병은 아래 <표 $2>$ 와 같다.

\section{〈표 2〉 남성과 여성의 DALY 차이가 큰 질병}

2016년 기준(단위: number)

\begin{tabular}{|c|c|c|c|c|}
\hline \multirow{2}{*}{\multicolumn{2}{|c|}{ 질병 }} & \multicolumn{2}{|c|}{ 성별 } & \multirow{3}{*}{$\begin{array}{r}\text { 차이(여성-남성) } \\
10,016,792\end{array}$} \\
\hline & & \multirow{2}{*}{\begin{tabular}{|c|} 
남성 \\
$12,412,487.15$
\end{tabular}} & \multirow{2}{*}{\begin{tabular}{c|} 
여성 \\
$22,429,278.77$
\end{tabular}} & \\
\hline \multirow{5}{*}{$\begin{array}{c}\text { 전염성, } \\
\text { 신생아, } \\
\text { 영양 }\end{array}$} & Dietary iron deficiency & & & \\
\hline & Other meningitis & $4,323,947.84$ & $4,886,001.36$ & 562,054 \\
\hline & Whooping cough & 2,846,297.51 & $3,403,559.69$ & 557,262 \\
\hline & lodine deficiency & $1,350,244.74$ & $1,890,340.82$ & 540,096 \\
\hline & $\begin{array}{l}\text { Sexually transmitted diseases } \\
\text { excluding HIV }\end{array}$ & $5,753,012.62$ & $6,262,975.26$ & 509,962 \\
\hline \multirow{7}{*}{ 비전염성 } & Breast cancer & $254,149.03$ & $14,853,663.98$ & $14,599,515$ \\
\hline & Migraine & $16,041,039.14$ & $29,080,869.77$ & $13,039,831$ \\
\hline & Low back and neck pain & $38,406,784.04$ & $48,177,732.47$ & $9,770,948$ \\
\hline & Depressive disorders & $17,465,934.25$ & $26,742,479.17$ & $9,276,545$ \\
\hline & $\begin{array}{l}\text { Alzheimer disease and other } \\
\text { dementias }\end{array}$ & $11,228,592.26$ & $17,535,517.51$ & $6,306,925$ \\
\hline & Other musculoskeletal disorders & $12,250,139.06$ & $18,278,419.22$ & $6,028,280$ \\
\hline & Skin and subcutaneous diseases & $26,773,892.05$ & $30,620,130.57$ & $3,846,239$ \\
\hline \multirow{3}{*}{ 부상 } & Sexual violence & $471,887.88$ & $893,946.09$ & 422,058 \\
\hline & Foreign body in eyes & $130,467.28$ & $55,318.07$ & $-75,149$ \\
\hline & Exposure to forces of nature & $387,502.29$ & $229,581.57$ & $-157,921$ \\
\hline
\end{tabular}

출처: GHDx 홈페이지(http://ghdx.healthdata.org/gbd-2016) (접속일: 2018.07.10.) 내용을 바탕으로 저자가 재구성

전염성 질환에서는 식이성 철분 결핍, 뇌수막염, 백일해, 요오드 결핍, HIV를 제외한 성 전염성 질환이었다. 또한 비전염성 질환에서는 유방암, 편두통, 요통 및 경부통, 우울 장애, 치매, 근골격계 질환, 피부 및 피하 질환 순으로 DALY 차이가 크게 나타났다. 또 부상에서는 여성이 남성과 비교해 성폭력만이 더 많이 나타났으며, 나머지는 남성의 DALY가 여성보다 높았다.

\section{3) 여성의 질병부담이 높은 질병의 지역별 · 소득별 분포}

<표 2>에 근거해 여성의 DALY가 남성의 것보다 높은 질병 중, 전염성이거나 영양 관련 질병인 식이성 철분 결핍(dietary iron deficiency), 뇌수막염(Other meningitis), 백일해 
(Whooping cough), 요오드 결핍(Iodine deficiency), HIV는 제외한 성매개질환(Sexually transmitted diseases excluding HIV)의 성별에 따른 소득과 지역별 DALY 분포를 아래 $<$ 그림 $3>$ 과 같이 살펴보았다.

전염성, 신생아, 영양 관련 질환을 소득과 지역 기준으로 살펴보면, 소득 기준으로는 저소득

국가가 그리고 지역 기준으로는 남아시아 및 사하라 이남 지역의 아프리카가 대상 질병으로 인한 DALY가 높았다.

전염성 질환의 경우, 소득수준과 질병부담(비율)은 단순 반비례해 저소득 국가에서 그 비율이 가장 높았고, 질병부담 수(인구) 기준으로는 - 인구수의 영향으로 - 저소득 국가에서 가장 높았다. 그리고 식이성 철분 결핍을 제외한 4개 질병(뇌수막염, 백일해, 요오드 결핍, HIV를

〈그림 3〉 전염성, 신생아, 영양 관련 질병(남성-여성 DALY 차가 큰 질병) 지역별 · 소득별 차이(2016년 기준)

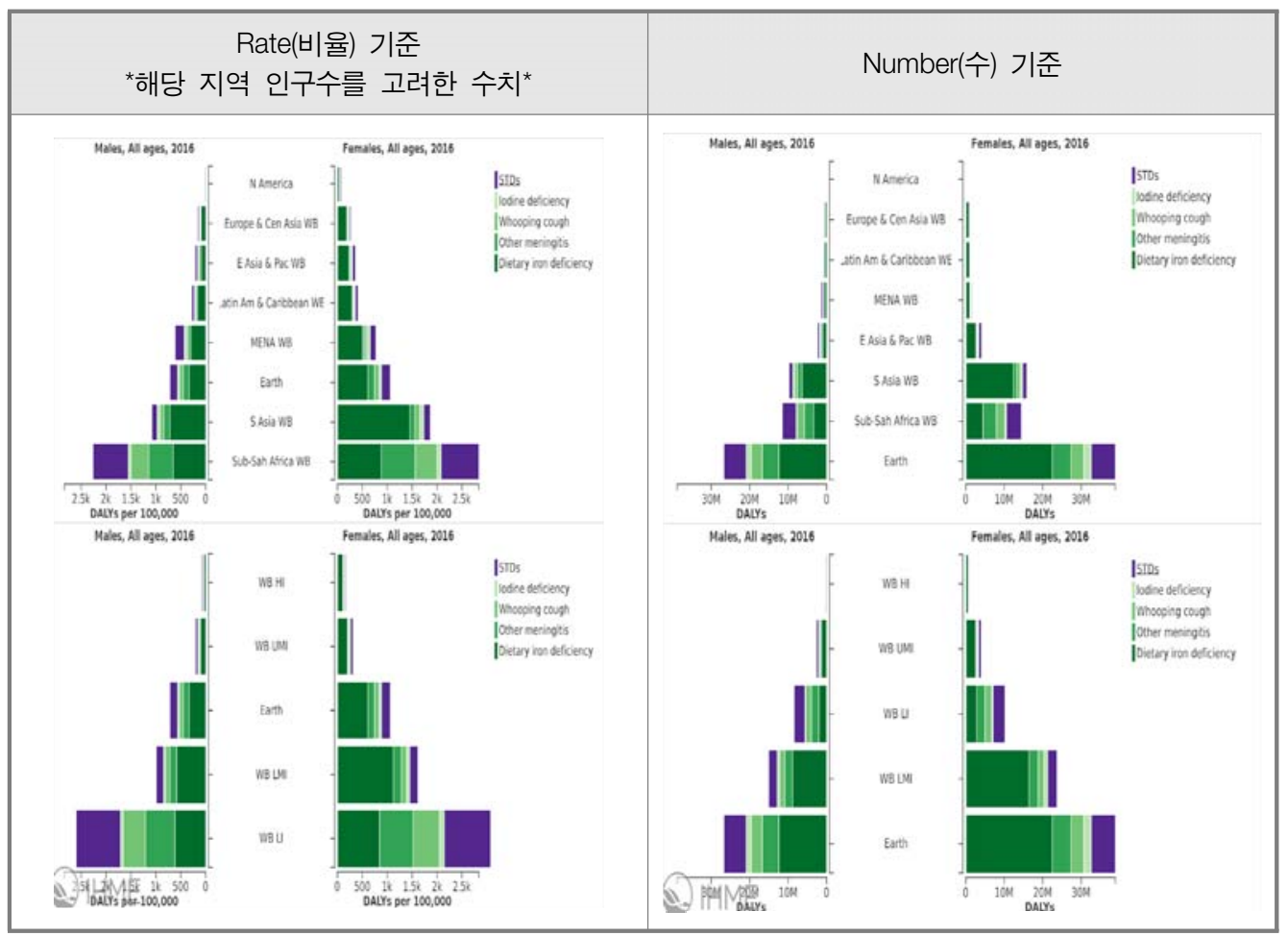

출처: GHDx 홈페이지(https://vizhub.healthdata.org/gbd-compare) (접속일: 2018.06.29.) 내용을 바탕으로 저자가 재구성

기준: 인구 10 만 명당 DALY(rate, number) 
이어 비전염성 질환의 경우에는 유방암(Breast cancer), 편두통 (Migraine), 요통 및 경부 통(Low back and neck pain), 우울 장애(Depressive disorders), 치매(Alzheimer disease and other dementias), 기타 근골격계 질환(Other musculoskeletal disorders), 피부 질환 (Skin and subcutaneous diseases)에 대해 소득과 지역별 DALY 분포를 아래<그림 4>와 같이 좀 더 세부적으로 살펴보았다.

Rate를 기준으로 할 때 고소득 국가와 북미 지역의 질병부담이 가장 높았으나, 단순 질병부담 수로는 중·저소득 국가 및 동아시아-태평양 지역이 높았다.

〈그림 4〉 비전염성 질병(남성-여성 DALY 차가 큰 질병) 지역별 · 소득별 차이(2016년 기준)

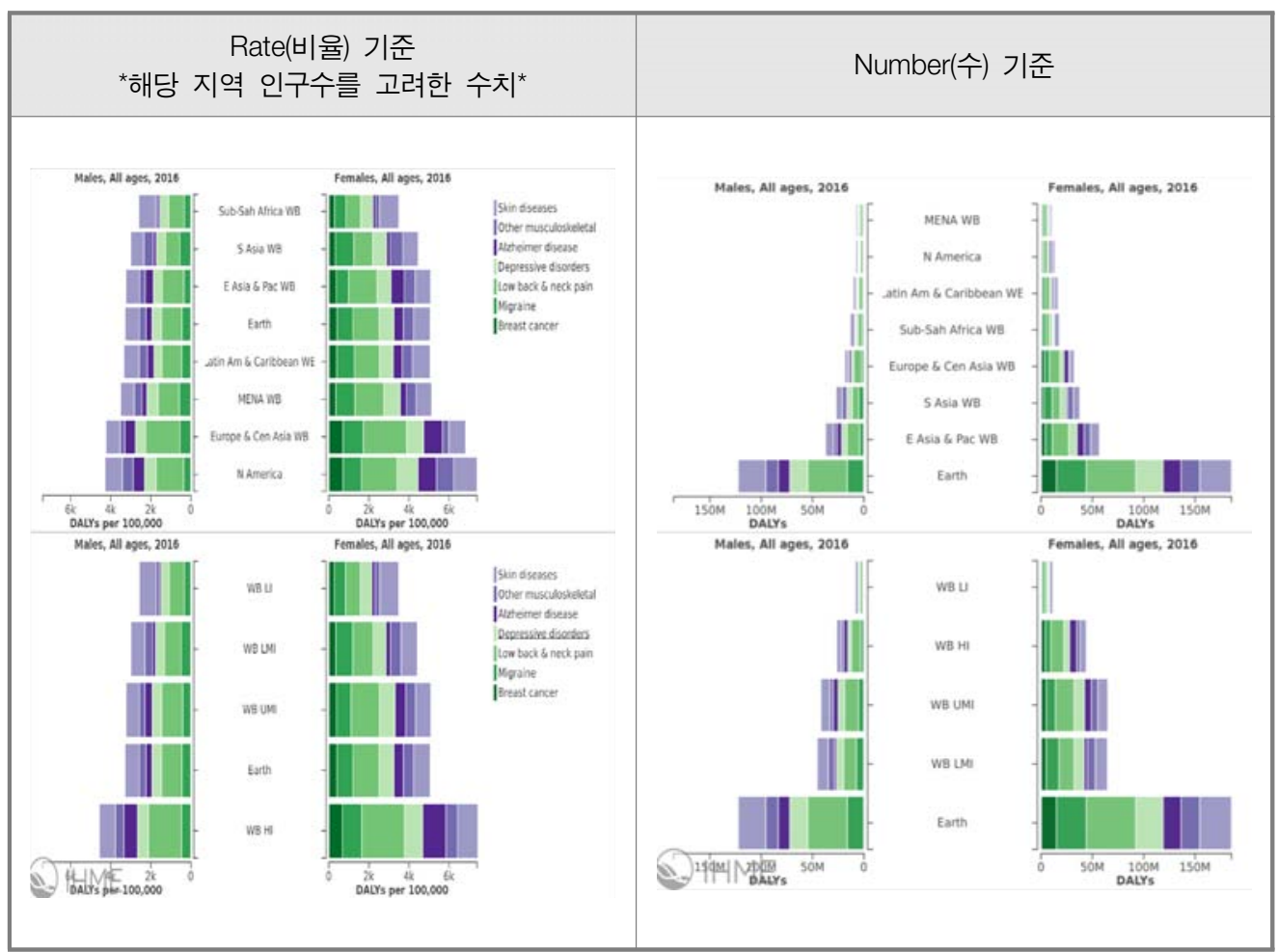

출처: GHDx 홈페이지(https://vizhub.healthdata.org/gbd-compare) (접속일: 2018.06.29.) 내용을 바탕으로 저자가 재구성

기준: 인구 10 만 명당 DALY(rate, number) 
4) 세부 질병의 성별 · 지역별 · 소득별 분포

(1) 식이성 철분 결핍

전염성 질병 중 식이성 철분 결핍에 따른 DALY의 남녀 차이를 살펴보면 아래<그림 $5>$ 와 같다. 남성에게 있어 식이성 철분 결핍으로 인한 $\mathrm{DALY}$ 는 15 세 이전에 편향되어 있었으나, 여성의 질병부담은 49 세까지도 100 만 명을 넘으며 많은 연령대에서 질병부담이 높았다.

〈그림 5〉 식이성 철분 결핍에 따른 남녀의 DALY 비교(2016년 기준)

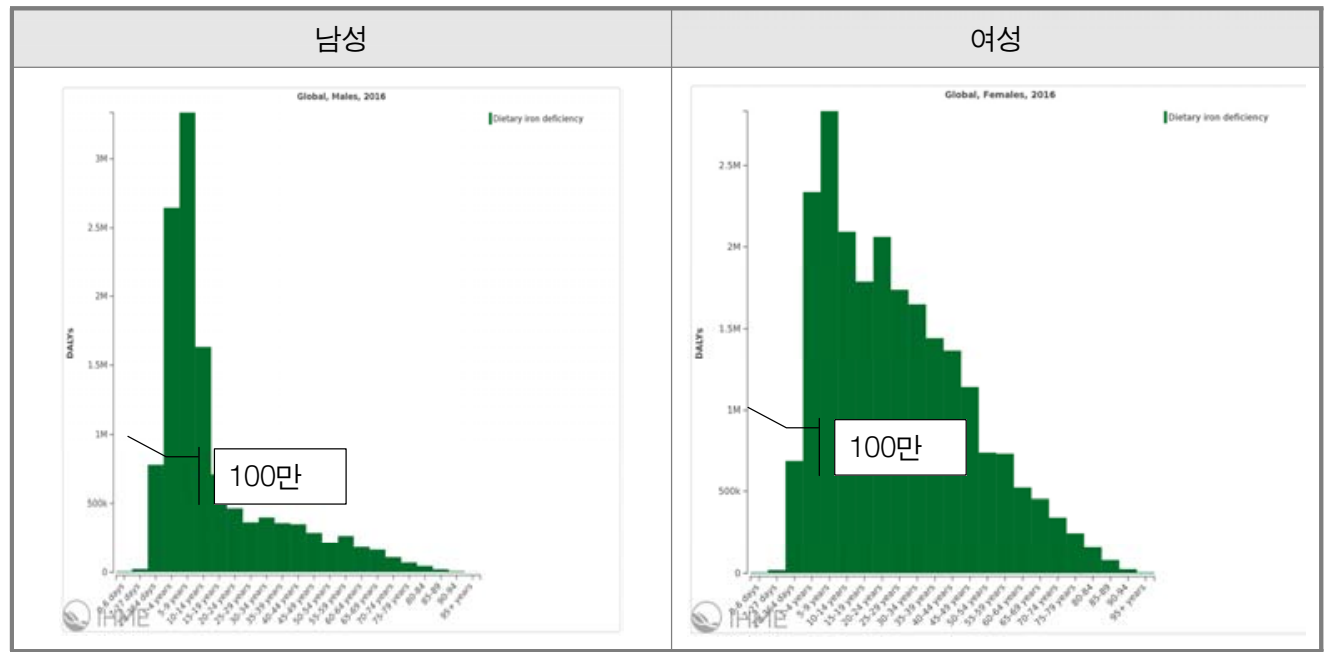

출처: GHDx 홈페이지(https://vizhub.healthdata.org/gbd-compare) (접속일: 2018.05.30.) 내용을 바탕으로 저자가 재구성

기준: 인구 10 만 명당 DALY(number)

지역과 소득별로 남녀 차이를 비교해 봤을 때 남아시아에서 DALY가 가장 높았으며, 남녀 차이 또한 컸다. 이때 여성의 경우, 남아시아는 남아시아를 제외한 모든 지역의 DALY를 합친 것보다 컸다. 또한 소득수준에 따라 DALY를 계산한 결과, 중·저소득 국가에서 질병부담이 가장 높았다. 이후 저소득 국가, 중상소득 국가, 고소득 국가 순으로 질병부담이 높았다. 이러한 순서는 인구 십만 명당 질병부담의 비율을 고려한 비율(rate)을 기준으로 보았을 때도 동일했다.

(2) 요오드 결핍

요오드 결핍에 대한 남녀의 DALY 차이는 아래<그림 $6>$ 과 같다. 남성과 여성의 연령에 따른 질병부담 변화 양상은 비슷했으나(그래프의 모양이 유사), 연령별 요오드 결핍에 대한 $\mathrm{DALY}$ 는 여성이 더 높다는 것을 확인할 수 있다. 
〈그림 6〉 요오드 결핍에 다른 남녀의 DALY 비교(2016년 기준)

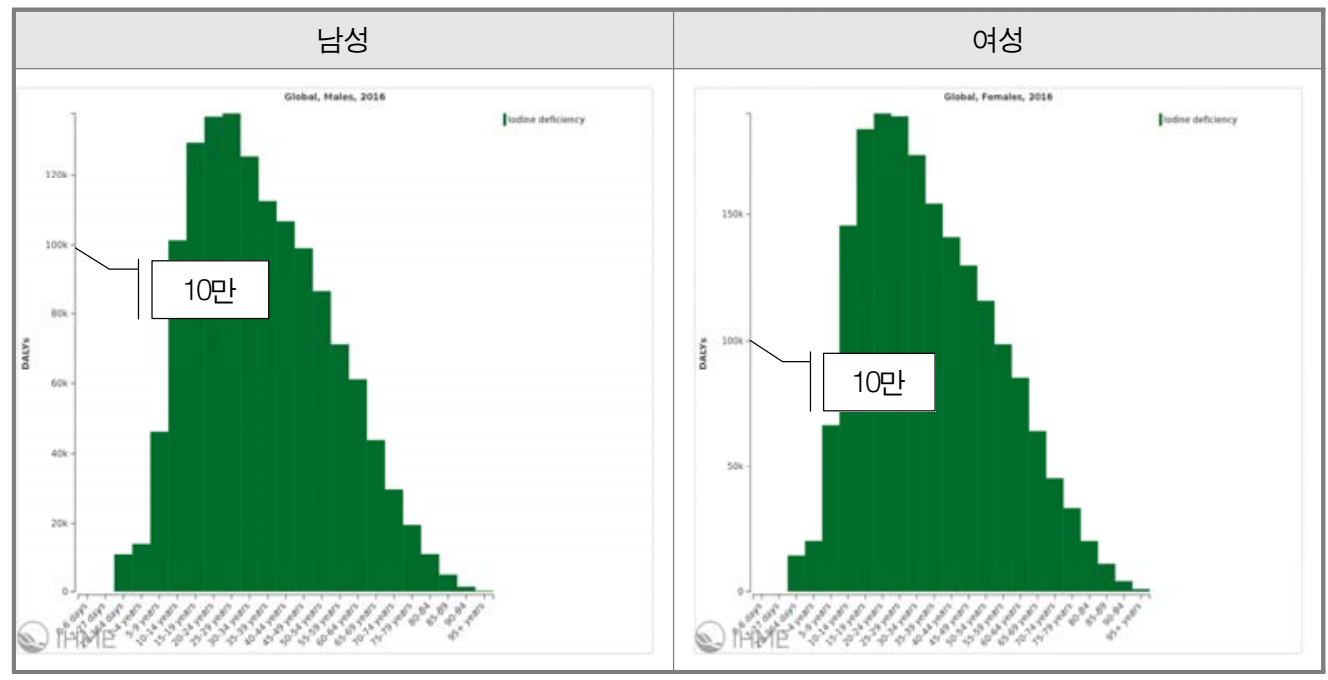

출처: GHDx 홈페이지(https://vizhub.healthdata.org/gbd-compare) (접속일: 2018.05.30.) 내용을 바탕으로 저자가 재구성

기준: 인구 10 만 명당 DALY(number)

지역과 소득별로 요오드 결핍에 대한 남녀의 질병부담 차이를 비교해 봤을 때 남아시아에서 DALY가 높았으며, 소득수준을 기준으로 비교해 봤을 때는 중·저소득 국가에서 질병부담이 높았다.

(3) $\mathrm{HIV}$ 를 제외한 성매개질환

$\mathrm{HIV}$ 를 제외한 성매개질환에 따른 DALY의 남녀 차이를 살펴보면 아래<그림 7>과 같다. 성인보다 5 세 이하 연령의 DALY가 높으며, 5 세 이하 연령의 사망자 수가 많은 반면, 성인은 해당 질병으로 인해 사망보다는 질병이환(Years Lost due to Disability, YLD)이 높기 때문 이다. 따라서 영아가 걸리면 치사할 정도의 병이지만 성인에서는 비교적 사망보다는 이환으로 남는다고 해석할 수 있다. 더불어 남성과 여성에 있어 $\mathrm{HIV}$ 를 제외한 성매개질환으로 인한 질병부담 수의 연령별 분포 형태는 유사했으나, 연령의 증가에 따라 DALY 수가 감소할 때 그 양상이 여성에서 더 완만하다는 것 또한 확인할 수 있다. 
〈그림 7〉 HIV를 제외한 성매개질환에 따른 남녀의 DALY 비교(2016년 기준)

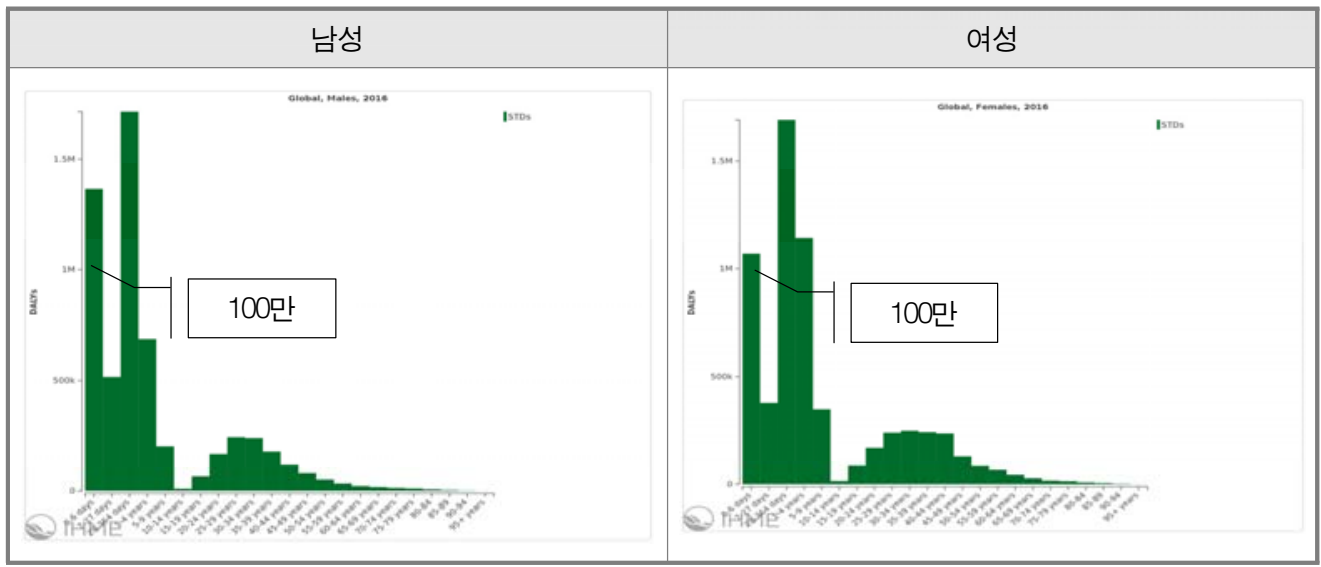

출처: GHDx홈페이지(https://vizhub.healthdata.org/gbd-compare) (접속일: 2018.06.30.) 내용을 바탕으로 저자가 재 구성

기준: 인구 10 만 명당 DALY(number)

지역과 소득별로 성별을 고려한 분포를 살펴봤을 때, 사하라 이남 지역 아프리카에서 질병부 담이 가장 높았다. 또한 소득수준에 따라 질병부담 수를 봤을 때는 저소득 국가에서 질병부담이 가장 높았으며, 소득수준과 질병부담은 반비례한다는 것을 확인할 수 있었다. 이러한 순서는 비율(rate)로 분석해도 동일하다.

(4) 우울증

비전염성 질환 중 우울증을 먼저 살펴보면, 남성과 여성의 우울 장애로 인한 DALY의 연령별 분포 형태는 아래 <그림 8>과 같이 유사했으나, 남성의 경우에는 25 29세에 약 160만 명이며 또 여성의 경우에는 45 49세에 약 240 만 명으로 나타나 여성의 부담이 더 높다는 것을 확인할 수 있었다. 
〈그림 8〉 우울증에 따른 남녀의 DALY 비교(2016년 기준)

남성

출처: GHDx홈페이지 (https://vizhub.healthdata.org/gbd-compare)(접속일: 2018.06.30.) 내용을 바탕으로 저자가 재구성 기준: 인구 10 만 명당 DALY(number)

지역별로는 동아시아-태평양 지역에서 DALY가 가장 높았으며, 소득별로는 중·저소득 국가, 중상소득 국가, 고소득 국가, 저소득 국가 순으로 DALY가 높게 나타났다.

(5) 알츠하이머

알츠하이머에 대한 남녀의 DALY 차이는 아래 <그림 9>와 같다. 남성과 여성의 DALY 분포는 유사했으나, DALY가 가장 높은 시점은 상이했다. 남성의 경우에는 80 84세(약 240만 명), 여성의 경우에는 80 84세(약 370만 명)에 가장 높았다.

\section{〈그림 9〉 알츠하이머에 따른 남녀의 DALY 비교(2016년 기준)}

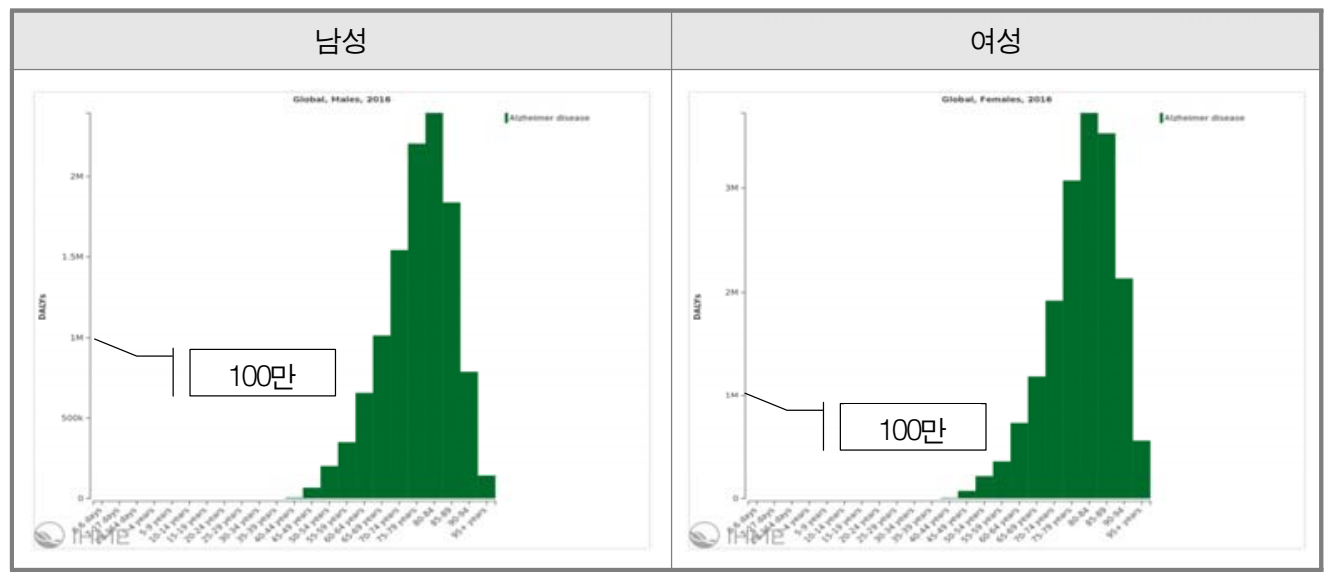

출처: GHDx홈페이지(https://vizhub healthdata.org/gbd-compare)(접속일: 2018.06.30.) 내용을 바탕으로 저자가 재구성 기준: 인구 10 만 명당 DALY(number) 
우울증과 동일하게, 지역별로는 동아시아-태평양 지역에서 DALY가 가장 높았으며 또 소득 별로는 중·저소득 국가, 중상소득 국가, 고소득 국가, 저소득 국가 순으로 DALY가 높게 나타났 다. 2000년 대비, 60세 이상에서 알츠하이머의 DALY가 지속적으로 증가했으며, 특히 동아시 아 태평양 지역에서 그 증가폭이 약 2 배로 높았다. 


\section{II. 원인 분석(Root Cause Analysis)}

건강에 있어 젠더불평등은 여성의 건강(women's health)만을 의미하는 것은 아니며, 다만 동 보고서에서는 개발도상국의 여성 관점에서 건강불평등을 다루고, 그 원인을 찾아보고자 했다. 원인을 찾기 위해 Ishikawa의 (Fishbone) Diagram을 이용한 Root Cause 분석을 했다(아래 <그림 $10>$ 참조).

〈그림 10〉 개발도상국 여성 건강불평등에 따른 Root Cause 분석

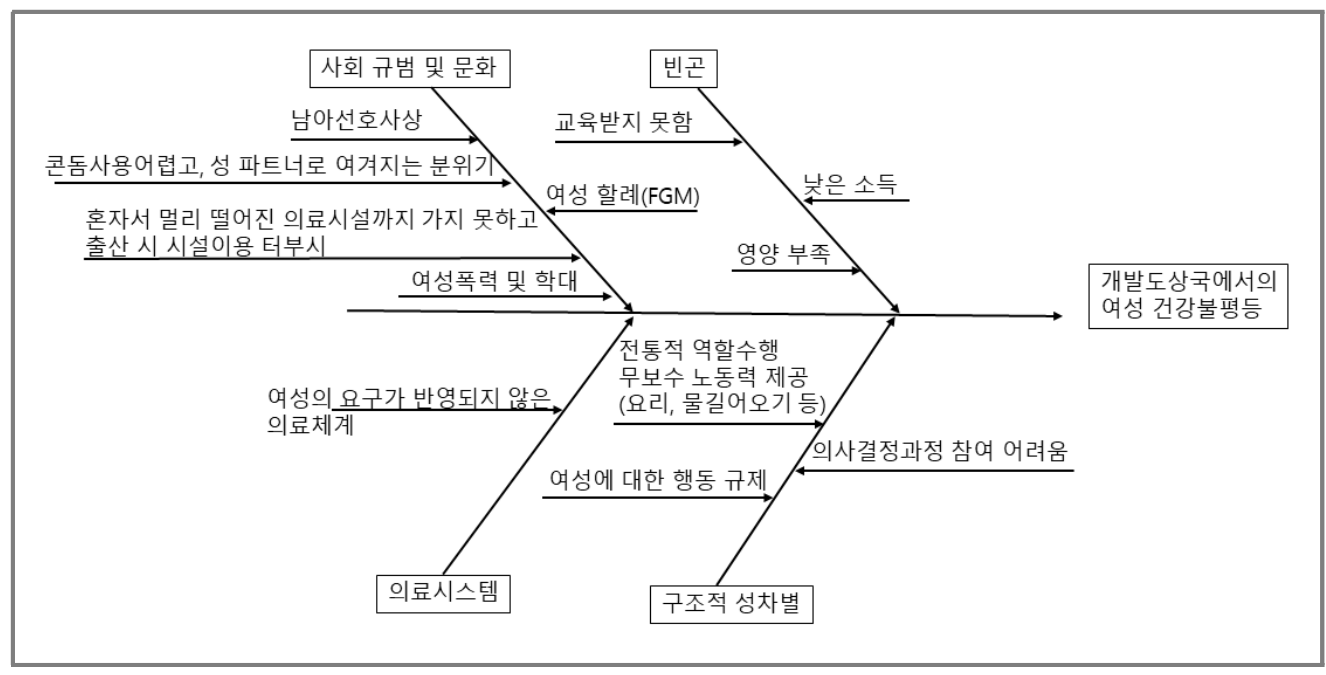

출처: 저자 작성

우선, 전반적인 여성의 건강불평등에 따른 원인을 살펴보고, 이후에 남성에 비해 여성의 질병 부담(DALY)이 높은 질병이었던 1) HIV를 제외한 성매개질환, 2) 알츠하이머, 3) 우울증을 대상으로 그 원인을 살펴보고자 한다.

\section{1. 개발도상국 여성의 건강불평등 원인}

1) 사회적 규범 및 문화

(1) 남아선호사상

사회적 규범 및 문화는 여성과 남성의 역할과 행동에 영향을 준다. 여성의 건강에서 불평등을 사회규범 및 문화적 측면에서 살펴보면 남아선호사상, 여성 할례(Female Genital mutilation, 
$\mathrm{FGM}$, 여성이 콘돔 사용을 요구하기 힘들고 또 여성을 성 파트너로 여기는 사회 분위기, 혼자서 멀리 떨어진 의료 시설까지 이동하거나 출산 시 의료 시설을 이용하는 것을 터부시하는 문화, 여성에 대한 폭력과 학대 등이 여성의 건강불평등에 영향을 주는 요인이라고 볼 수 있다.

특히, 남아선호사상은 많은 문헌에서 지적하는 요인이다. Aparna Mitra(2015)는 인도의 국가가족계획조사(The census of India and the National Family Health Survey)에 따르 면, 2001년 남아와 여아의 비율은 100 : 93이며, 1991년의 비율(100:98)과 비교하면 크게 감소 한 수치임을 밝히고 있다.

이러한 현상은 2000년대 초반의 남아선호사상과 더불어 태아의 성별 감별이 용이(초음파 검사의 접근성 향상)해짐에 따라, 여아일 경우에는 낙태하는 사례가 많아졌기 때문이다. 남아선 호사상은 낙태뿐 아니라 어린 시절 부모가 영양 공급과 의료 서비스 제공에 있어 다른 남자 형제와 여아를 차별할 수 있어, 여아의 건강을 상대적으로 나빠지게 만들 수 있는 요인이 된다.

(2) 여성 할례(Female Genital mutilation, FGM)

여성 할례는 치료의 목적이 아닌, 성 인식이라는 명분으로 여성 성기의 전체 혹은 일부를 제거하는 의식이다. 이는 소녀들이나 여성들의 건강에 있어 혜택은 전혀 없고, 나쁜 영향만을 끼친다. 할례를 시행한 직후에는 고통, 열, 감염, 출혈, 소변 배출 문제, 정신적 충격 등을 겪게 된다. 또한 장기적으로는 대소변 문제, 흥터와 켈로이드, 출산 시 과다 출혈 혹은 자연분만 실패 등의 위험을 동반한다. 따라서 여성 할례는 개발도상국 여성의 건강불평등 요인 중 하나다.

$\mathrm{WHO}$ (2018)에 따르면 현재 아프리카, 중동 및 아시아의 30 개 국가에서 2 억 명의 소녀와 여성들이 여성 할례를 경험하고 있다. 주로 유아기에서 15 세 사이에 대부분 시행된다. 그 이유는 다양한데, 여성 할례를 시행하는 지역에서는 할례가 성인이 되어 가는 과정에서 거쳐야 하는 의식이며, 할례를 받지 않은 여성은 불결하다는 사회적 규범(social norm)이 형성되어 있기 때문이다.

(3) 여성이 콘돔 사용을 요구하기 힘들고, 여성을 성 파트너로 여기는 사회적 분위기

Rachel Mash(2010)에 따르면, 콘돔은 성적 즐거움을 감소시키고 또 신뢰와 반대되는 의미 를 가진다는 잘못된 인식이 존재한다. 또한 성적 의사 결정에 있어 여성이 불평등한 권력 관계에 놓여 있으므로, 남성들이 콘돔을 사용하지 않는 것에 대해 반대 의사를 강하게 밝히지 못한다고 설명한다. 콘돔 미사용은 여성들이 성매개질환(Sexually Transmitted Disease, STD)에 감 염될 확률이 더욱 높은 것은 물론 원치 않는 임신, 낙태 등으로 이어질 수 있다. 특히, 개발도상국 
의 국경 지방에 거주하는 여성들은 경제적 목적으로 여러 파트너와 성관계를 맺는 경우가 있는 데, 이때 성매개질환에 취약하다.

더불어 개발도상국의 소녀는 낮은 사회적 지위로 인해 소외된 계층에 포함되며, 효과적인 family planning service(콘돔 사용 등) 프로그램에 접근하기도 쉽지 않다. 따라서 성매개질환 에 대한 감수성이 민감하지 않고, 콘돔의 중요성을 잘 인지하지 못하며, 감염되었을 때 주변의 지지나 적절한 치료를 받기 어려운 집단으로 분류되어 특히 취약하다고 볼 수 있다.

(4) 혼자서 먼 거리에 있는 의료 시설까지 이동 및 출산 시 의료 시설 이용을 터부시하는 문화

개발도상국의 여성, 특히 도시와 떨어진 시골 지역으로 갈수록 의료 접근성이 떨어진다. 또한 가정 내 의사 결정 권한이 약해지며, 이는 여성이 의료 시설을 이용하는 데도 영향을 미친다. 예를 들어, 출산을 할 때 여성이 의료 시설에 도착해 적절한 관리와 치료를 받는 데 있어 지연되 는 3 가지 요인이 있다. 이를 설명하는 3 Delay model(아래 <그림 $11>$ 참고)에서 첫 번째 장벽인 '치료를 받으러 가기를 결정하는 단계(Deciding to Seek Care)'가 이에 해당된다. 적절한 관리와 치료가 필요함에도 불구하고, 여성이 혼자서 먼 거리에 있는 의료 시설까지 이동하는 것을 터부시한다거나, 가족 구성원들(시어머니, 남편 등)들이 전통적인 출산 방법을 고수하는 경우에 여성은 이로 인해 관련 질병에 노출될 수 있다.

〈그림 11〉 3 Delay Model

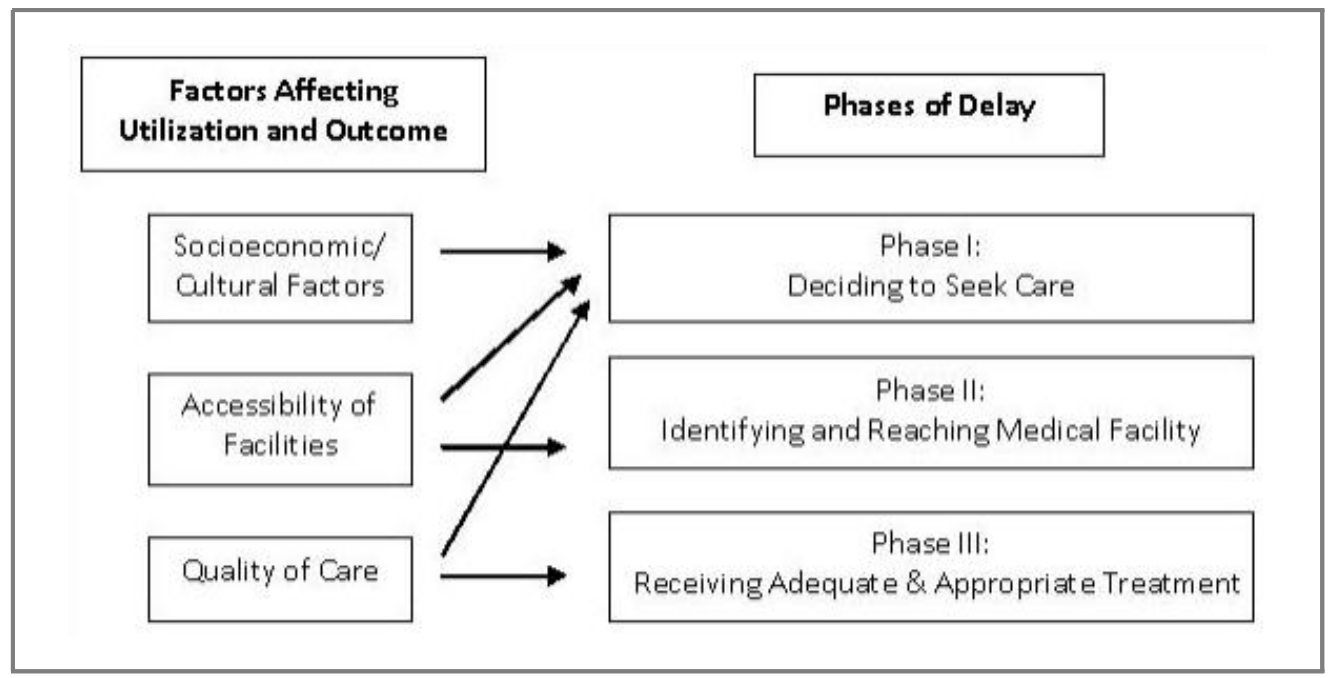

출처: Thaddeus (1994) 
(5) 여성에 대한 폭력과 학대

여성에 대한 폭력과 학대는 전 세계적으로 발생한다. 특히, 개발도상국에서는 여성이 남성보 다 낮은 지위에 있다고 생각하는 가부장적인 체제하에서 물리적·감정적·성적 폭력과 학대가 발생한다. 아울러 개발도상국의 남녀 아동들이 모두 영양실조·성적 학대·폭력 등을 경험하는 데, 특히 소녀들의 경우에는 소년들보다 성적 학대를 더 많이 경험한다. Ezzati(2004)에 의하면, 조사 결과 $25.3 \%$ 의 소녀들이 성적 학대를 경험했으며, 이는 소년들이 경험한 $8.7 \%$ 의 3 배에 달한다고 제시하고 있다.

이러한 폭력과 학대는 소녀와 성인 여성에게 모두 단기적 혹은 장기적으로 건강에 영향을 끼친다. 결과적으로 신체적 상해, 출산 시 위험, 정신적 트라우마를 가져오며 또 우울증 및 스트레스 장애, 알코올 및 약물 복용 및 의존, 성 전염 질환, 자살 시도 등으로 이어질 수 있다. 한편, $\mathrm{WHO}(2005)$ 는 이처럼 학대를 당하지 않은 그룹에 비해 원치 않는 임신, 낙태, 신생아 및 유아와 관련된 문제, $\mathrm{HIV}$ 등의 성 전염 질환, 수면 장애 등을 겪을 확률이 더 높다고 지적하고 있다.

(6) 빈곤

빈곤은 사회·문화적 분위기와 결합해 작동하면서 여성의 건강 문제에 영향을 주게 된다. 개발도상국의 많은 커뮤니티나 가정에서 여성들에게 교육을 받게 하고 또 영양이 충분한 음식을 제공하고 싶더라도, 경제적인 어려움과 한정된 자원 때문에 몇몇 소수만 교육 혹은 고용의 기회를 누릴 수 있다. 이때 남성이 여성보다 높은 위치에 있다는 사회적 인식에 따라 대부분 남성들이 우선적으로 기회를 받게 된다. 교육의 기회, 상대적으로 부족한 영양 섭취 혹은 소득 창출의 기회를 상실하는 것은 결국 여성 건강에 나쁜 영향을 끼치게 된다.

(7) 구조적 성차별

사회구조적 성차별은 여성의 건강에 간접적인 영향을 미친다. 예를 들어, 개발도상국의 많은 여성이 공식적인(informal) 노동 시장의 일원으로서 일하는 경우가 적고, 전통적인 여성의 역할에 따라 가사에 국한되거나 혹은 무보수 노동을 하는 경우가 많다. 이에 따라 고용 안정 및 건강관리와 관련된 사회보장 혜택에 대한 접근성이 부족한 경우가 많다. 또한 무급 가사 노동만을 하게 되면 교육과 정규직에 대한 여성의 기회가 줄어들고, 이 역시 간접적으로 볼 때 장기간 건강관리에 소홀할 수밖에 없는 환경에 놓일 수 있다. 개발도상국의 여성이 장시간의 조리 및 가족을 위한 식사 준비 시, 재래식 고체 연료에서 나는 연기로 인해 관련 질환(만성폐색 성 폐질환 등) 인자에 쉽게 노출되는 것이 대표적인 예라고 할 수 있다. 
(8) 의료 시스템

Gita Sen and Piroska Östlin(2007)에 따르면, 많은 국가의 보건 체계(health system)에서 젠더 평등을 적절히 이행하는 경우가 드물다. 다수의 보건 체계에서 남성과 여성의 건강 요구가 서로 다를 수 있다는 점을 무시한다는 의미로, 의료 시설에서조차 여성을 삶의 질을 제공해야 할 대상으로 보지 않고 다른 수단적 존재로 본다는 것이다. 산부인과의 경우, 치료 및 관리의 목적을 여성의 삶의 질 관리가 아닌 출산력 조정(control) 관점에서 접근하고 있다. 또한 여성들 이 의료 시설에 더 많이 근무하지만, 아이 돌보기 및 폭력 예방과 같은 여성이 가질 수 있는 특별한 필요(needs)가 반영되지 않고, 남성 위주의 환경이 조성된다고 지적하고 있다.

\section{2. $\mathrm{HIV}$ 를 제외한 성매개질환}

본 장에서는 HIV를 제외한 성매개질환(Sexually Transmitted Disease excluding HIV) 과 관련된 건강불평등의 원인에 대해 자세히 살펴보고자 한다.

우선, 질병부담의 남녀 차이를 세부 범주로 나누어 살펴보면 트리코모나스 감염 및 기타 성매개질환에서 남녀 간 차이가 컸다. 또한 전반적으로 성매개질환과 관련해 여성 부담이 남성 보다 높다는 것을 확인할 수 있었다. 반면, 상대적으로 남성의 부담이 더 높은 임균 감염과 (여성에게만 나타는 것으로 보고되는) 트리코모나스 감염의 경우는 예외로 볼 수 있다. 이러한 현황을 고려해, 아래 <그림 $12>$ 에서는 그 원인을 구조화해 살펴보고자 한다.

〈그림 12〉 개발도상국의 HIV를 제외한 성매개질환 Root Cause 분석

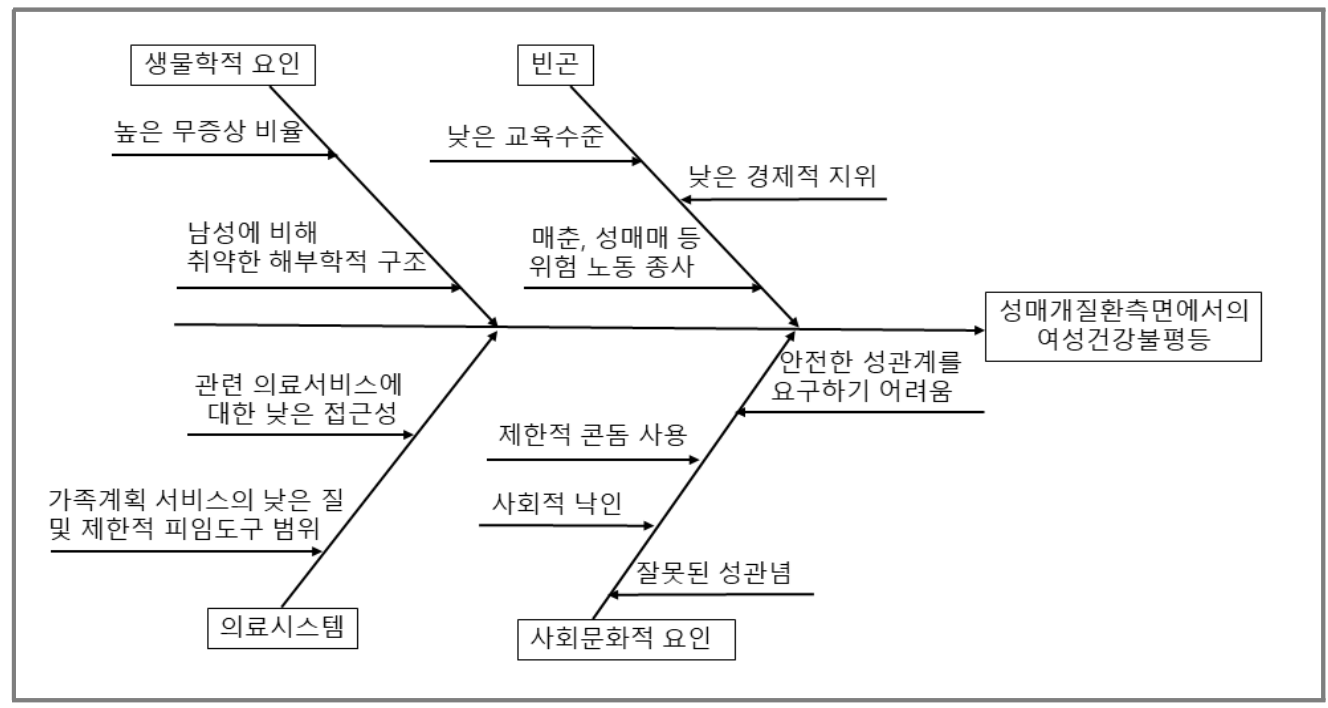

출처: 저자 작성

92 | 국제개발협력 
특히, 성매개질환은 개발도상국의 성인들이 진료를 가장 받고자 하는 상위 5 개의 질병 범주에 속한다. 성매개질환을 제때 치료하지 못하면 심각한 영향을 초래하거나 장기적으로 지속될 수 있어 주의가 요구된다. 특히, 여성의 경우에는 남성에 비해 더 많은 영향을 받으며, 적절한 진단이나 치료를 받지 못할 때는 자궁경부암, 골반염, 불임, 자궁외임신 및 모성 사망으로까지 이어질 수 있는 만큼 위험이 높다. 한편, 신생아들 또한 감염된 산모로부터 성매개질환이 옮아 선천성 매독 등의 심각한 위험에 노출될 수 있다(UNAIDS, 1998).

\section{1) 생물학적 요인}

여성은 주요 성매개질환에서 남성에 비해 증상이 나타나지 않는 경우가 많다. 한 예로, 클라미 디아 및 임균 감염의 경우 대부분의 여성에게는 무증상을 보이나, 남성의 경우 최대 $90 \%$ 의 증상이 나타난다(UNAIDS, 1998). 또한 여성의 경우 한때 증상이 나타났다가도 시간이 지나 증상만 사라지고 질병은 계속 남아 있을 수 있어 진단을 쉽게 놓치기 쉽다. 또한 여성은 성 매개질환을 가벼운 질염 등으로 착각하고 지나치기도 하는데, 이에 반해 남성들은 평소와 달리 특별히 다른 징후가 나타나므로 신체적 이상을 감지할 확률이 높다(CDC, 2011).

여성에게 나타나는 또 다른 생물학적 특징으로는, 남성에 비해 취약하고 감염이 쉬운 해부학 적 구조를 지니고 있다는 점이다. 질의 벽(lining)은 남성의 생식기 표면에 비해 얇고 연약하므 로, 성 병균이 침투하기 쉽고 또 질의 습한 내부는 박테리아 등이 자라는 데 좋은 환경을 갖추고 있어 남성에 비해 면역학적으로 취약한 특성을 지닌다(CDC, 2011).

\section{2) 빈곤}

빈곤의 문제는 한 개인과 사회 전반에 지대한 영향을 미치며, 이는 건강 문제와도 떼려야 뗄 수 없는 관계를 지닌다. $2016 \mathrm{GBD}$ 연구를 바탕으로 성매개질환의 소득별 분포를 살펴보면 (아래 <그림 13> 참고), 남녀 모두 저소득 국가에서 가장 높은 질병부담을 보이고 있는 것으로 나타난다. 이를 통해 빈곤의 문제가 성매개질환에도 직간접적인 영향을 미치고 있다는 것을 알 수 있다.

$\mathrm{WHO}$ 에 따르면, 매년 약 340 백만 건의 치료 가능한 4대 주요 성매개질환(임질, 클라미디아 감염, 매독, 트리코모나스 감염)이 새로 발병하고 있으며, 그 중 $75 ~ 85 \%$ 가 개발도상국에 분포 하고 있는 것으로 나타났다(WHO, 2001).

아래 <그림 13>에서는 1990년부터 2016년에 이르기까지 HIV 외 성매개질환의 질병부담이 
전체적으로 감소하는 추세를 보이고, 고소득 및 저소득 국가 간 격차도 점차 축소되어 온 것을 확인할 수 있다. 그러나 2016년 기준으로 저소득 국가의 해당 질병부담이 나머지에 비해 상대적 으로 높게 나타나는 현상이 유지된다는 것을 확인할 수 있다. 이러한 상황은 질병으로 인한 사망과 이환 측면에서 개발도상국에 지대한 부담을 계속 주고, 더 나아가 기타 경제적·정치적. 사회문화적 요인 등과 결합해 빈곤의 악순환을 악화시키는 고리로 작용할 수 있다. 일례로, $\mathrm{HIV}$ 외 성매개질환은 15 44세 아프리카 여성의 건강수명 손실연수(healthy life years lost) 에 대한 두 번째로 가장 주요한 원인이다. 즉 전체 질병부담의 $17 \%$ 를 설명하는 요인으로 분석된 바 있다(World Bank, 1993).

\section{〈그림 13〉 소득별 HIV를 제외한 성매개질환 DALY 분포}

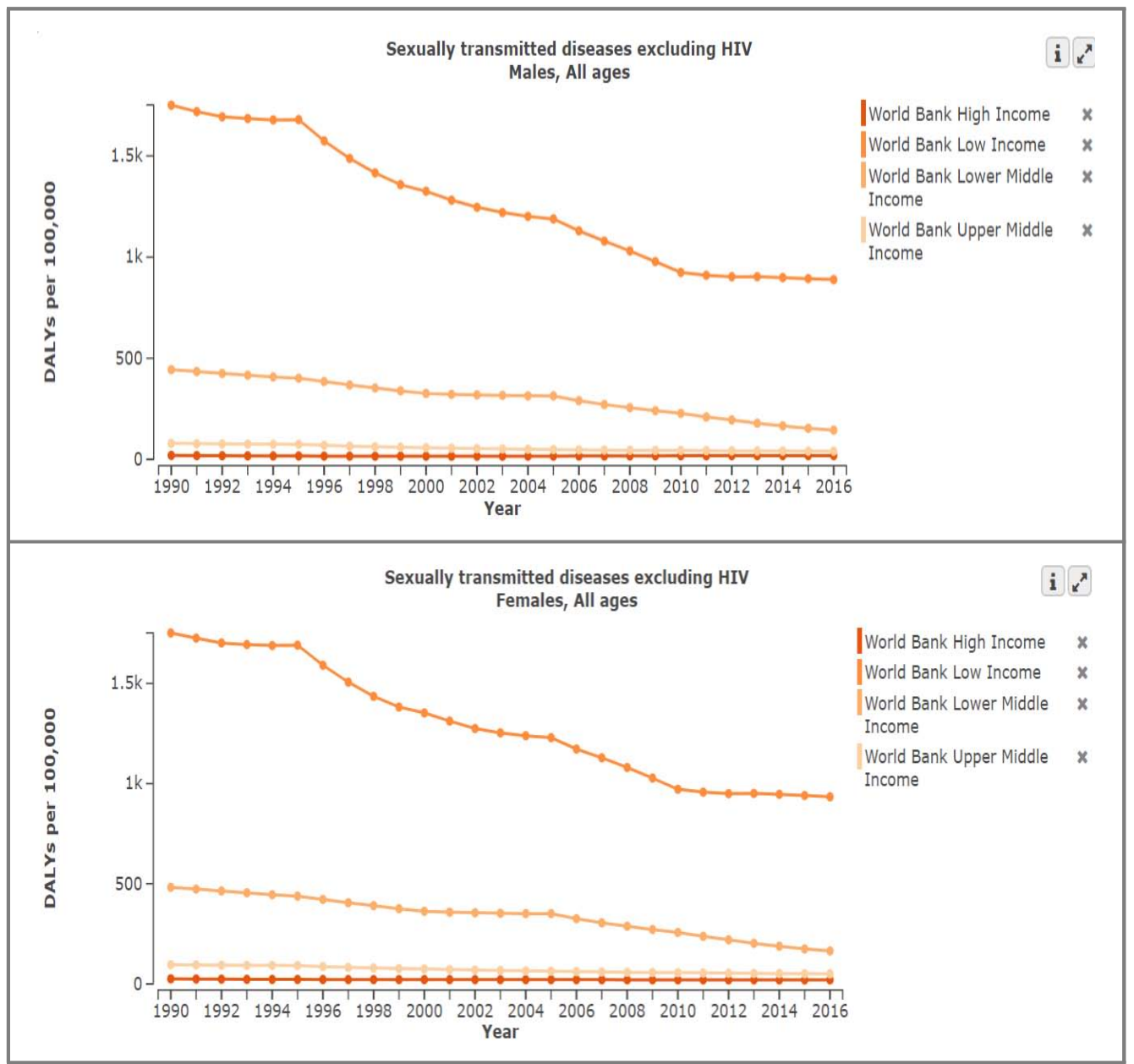

출처: GHDx홈페이지( https://vizhub.healthdata.org/gbd-compare) (접속일: 2018.06.30.) 내용을 바탕으로 저자가 재구성 
한편, 빈곤으로 인한 여성의 낮은 교육 수준은 성매개질환뿐만 아니라 보건의료 서비스 전반 에 대한 낮은 인식과 건강 추구 행동을 제한할 수 있다. 또한 교육 수준은 이들의 사회경제적 지위에도 상호 영향을 미친다. 이른바 가사 노동을 생산성이 없는 일로 취급하는 전통적 인식은 사회경제적으로 여성이 남편에게 전적으로 의존하는 관계를 형성하고, 더 나아가 여성에게 가정 내 합당한 지위나 의사 결정의 권한이 주어지지 않는 문제와도 연결될 수 있다. 이는 여성들이 보건 시설을 방문하고자 할 때 시어머니나 남편의 허락이 필요한 상황 등을 초래하고, 이의 중요성을 이해하지 못하는 가정이나 지역사회에서는 여성만의 노력으로 이러한 편견을 극복하기가 매우 어렵다.

아울러 여성들은 극단적인 경제적 어려움이 닥치면 생계를 위해 매춘이나 성매매 등을 하며 돈벌이 에 뛰어들게 되고, 무분별한 성관계에 노출됨에 따라 성매개질환에 대한 위험도 상승하게 된다.

제I장

\section{제II장}

포

\section{3) 의료 시스템}

특정 지역의 경우, 이용 가능한 성매개질환 관련 의료 서비스 자체가 존재하지 않기도 하다. 혹은 의료 서비스가 존재하는 경우, 특히 중·저소득 국가의 경우에는 보건 시설에 대한 지리적 접근성이 낮은 편이고, 경제적 취약성으로 인해 의료비를 지출하지 못하는 경우도 있다. 이러한 상황에서 여성과 아동이 가장 취약한 위치에 놓이게 된다(UNAIDS, 1998).

개발도상국 내 가족계획 서비스의 질은 점차 개선되어 왔으나 아직 부족한 실정이다. 따라서 여성의 생식 주기에 따라 필요한 피임 서비스를 받을 수 있도록 적절한 상담 서비스가 제공되는 것이 중요하다. 그러나 여성이 불만족스러운 서비스를 받았거나 의료 인력의 지도하에 피임에 실패하는 등의 경우가 발생하면, 여성은 피임을 쉽게 중단할 수 있게 된다. 이는 때에 따라 성매개질환의 위험성을 증가시키는 요인이 된다.

한편, 필수 의약품 리스트에 포함된 상품만을 이용해야 하는 국가에서 해당 리스트에 일부 피임제가 실수로 누락된 경우, 이용 가능한 피임 수단의 범위가 제한되는 상황이 발생하기도 한다. 결과적으로, 적절하게 구성된 피임 도구들을 제공하는 것은 $\mathrm{HIV}$ 및 성매개질환의 확산을 감소시키는 데 도움을 줄 수 있다(World Bank, 1993).

\section{4) 사회 · 문화적 요인}

일찍이 여성은 약하고 불완전한 존재로 인식되었고, 이에 비해 남성은 강하고 완전한 존재로 인식되는 경향이 나타나기도 했다. 또한 여성의 생식 주기, 즉 임신과 월경, 폐경 등은 질병으로 
생각되거나 여성의 가치를 떨어뜨리는 근거로 활용되기도 했다. 여성은 불결하고, 나약하며, 아픈 존재라는 사회적 인식은 여성이 남성을 감염시킬 수 있다는 불안감을 야기했다. 이에 따라 여성 자체가 성매개질환을 일으키는 원인으로 간주되었으며, 이는 여성이 위험한 존재라는 사회·문화적 이미지를 입증하는 방편으로 작용했다(Cecilia et al., 2010).

일례로, 베트남 북부에서 여성의 역할은 사회적으로 ‘아내와 어머니'로서 굳어져 있다. 그리고 이러한 역할에 대해 여성들은 남편에게 충실하고 순종적인 태도를 보여야 한다는 기대감이 있다. 남성의 경우, 결혼과 성 역할이 전통 규범에 그다지 명확히 정의되어 있지 않기에 혼전·혼 외정사에 대해 보다 관용적으로 받아들여지고 있다. 반면, 여성은 그런 행동들에 대해 가정 내에서 혹은 사회적으로 심한 규탄을 받는다(Vivian Fei-ling Go et al, 2002). 이러한 보수적 인 문화 속에서 여성은 스스로 사회적으로 배제되고 또 학대 등을 당할 것을 두려워해 성매개질 환에 대한 이야기 자체를 꺼내기가 두려울 수밖에 없다. 이에 따라 여성들은 적시에 필요한 진단이나 치료 서비스를 받을 수 있는 기회를 상실하게 된다.

콘돔을 지속적으로 혹은 적절하게 사용하는 것은 HIV 및 성매개질환을 예방하는 데 있어 가장 효과적인 보호 수단 중 하나다. 그러나 여성 및 청소년의 경우에는 질병의 예방법에 대해 무지한 경우가 많고, 또한 계획되지 않은 혹은 강요된 성관계로 인해 안전한 성관계를 협의할 수 없는 상황에 처하게 된다. 이러한 환경은 여성이 성매개질환에 자연스레 노출될 위험을 증가시키는데, 이는 남성과의 권력 관계에서 여성이 상대적으로 불평등한 위치에 놓인 상황에서 기인한다(Mayaud, P. et al., 2004).

사회적으로 소외된 여성은 성관계 시 콘돔 사용이나 기타 자신의 몸을 보호할 수 있는 수단을 주장하기 어렵고, 특히 결혼한 여성의 경우 남편으로부터의 보복이나 방치 등을 두려워해 결과 적으로 안전하지 못한 성관계에 참여하게 된다. 남녀 관계에 있어 문화적으로 깊이 뿌리박힌 성 역할과 권력 불균형은 이와 같이 여성의 자율성과 통제권을 침해하고, 여성의 성매개질환에 대한 노출 위험성을 증가시킨다(Cabral, R.J. et al., 1998).

한편, 성매개질환 등의 치료를 위해 환자가 의료 시설을 방문할 때 보건 시설 차원에서 이들에 대한 정보 보호나 기밀 유지가 잘 이루어지지 않는다. 그러다 보니 사회적인 낙인이 두려운 환자들은 괜한 오해가 생길 것을 우려해 시설을 방문하는 것 자체를 꺼리거나 치료를 중도에 포기하는 경우가 발생한다(UNAIDS, 1998). 더욱이 남성에 비해 사회경제적 지위가 낮은 여성 들은 이러한 인식에서 더욱 자유로울 수 없는 것이 현실이다. 이러한 문제들은 여러 가지 사회구 조적인 요인들이 복잡하게 얽혀 있기에 여성 스스로 혹은 어떤 단편적인 노력으로는 해결하기 힘든 측면이 있다. 


\section{3. 알츠하이머}

1) 생물학적 요인

알츠하이머에 가장 위험한 요소는, 연령이 증가하며 전 세계적으로 남성에 비해 여성의 수명

이 길다는 것이다. 전 세계 65 세 미만 노인의 치매 유병률은 $2 \sim 11 \%$ 이고, 노령 여성을 기준으로 76 세에 치매와 알츠하이머의 발병 확률이 높다. 치매는 질병으로 인한 사망이 아닌, 장애 (disability)로 인한 질병부담이 높다(Prince, 2015).

캐나다, 미국, 스웨덴, 홍콩에서 실시한 고소득 국가의 연구에 따르면, 뇌 및 정신장애(뇌졸중 및 우울증)가 치매에 많은 영향을 끼치는 것으로 나타났다. 또한 개발도상국에서는 고령자의

뇌졸중 및 혈관 인자가 알츠하이머 및 다른 치매의 위험을 증가시킨다.

\section{〈그림 14〉 개발도상국의 알츠하이머 Root Cause 분석}

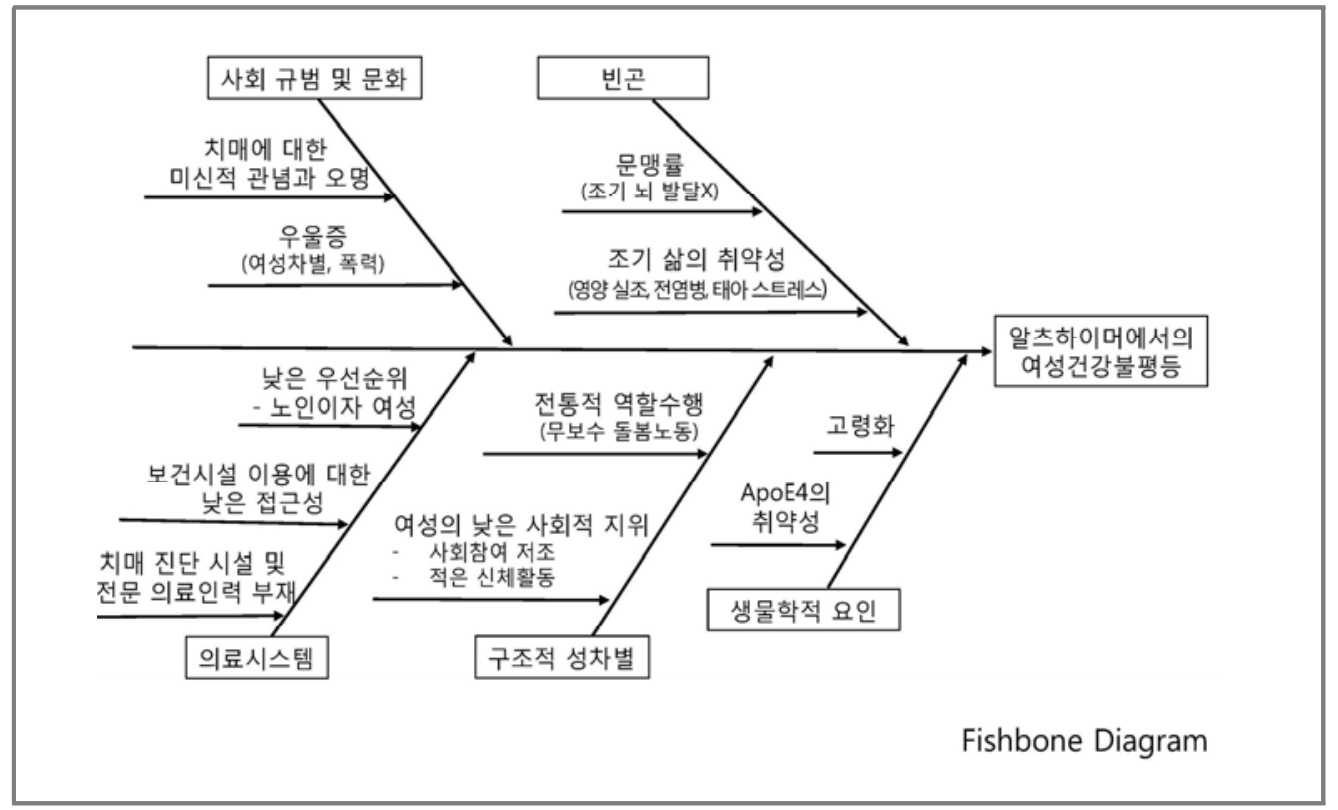

출처: 저자 작성

\section{2) 빈곤}

삶의 초기 전염병, 영양실조 및 태아 스트레스를 포함한 빈곤과 관련된 해로운 환경에 노출된 상황이 노화 과정에도 영향을 미치고, 우울증 또한 성별에 따라 치매의 위험 요소가 된다. 


\section{3) 사회 · 문화적 요인}

치매에 대한 인식 부족, 부적절한 진단, 보건 진료의 낮은 접근성, 간호비용, 이로 인한 건강의 악화가 치매 위험의 증가와 관련이 있다. 많은 문화권에서 여성은 가족을 돌보는 사람으로서 일한다. 치매 환자의 간병인 중 $60 \sim 70 \%$ 는 여성이며, 간병 여성의 대부분은 65 세 이상으로 간병 부담의 어려움이 가중된다. 집 밖에서 일할 가능성이 낮다는 여성에 대한 사회·문화적 기대 및 고정된 성 역할로 인해 여성의 간병인 부담이 크다(Kalaria et al, 2008).

\section{4. 우울증}

여성은 남성에 비해 약 두 배 정도의 우울증을 경험한다. 우울증의 발병 원인은 생물학적 요인, 행동적 요인, 외부환경과 연관되어 나타나는 생활 사건 등으로 나누어 볼 수 있다. 남성에 비해 여성에게 우울증으로 인한 질병부담이 더 많이 나타나는데, 우울증 발병의 원인 및 우울증 의 치료법 이용을 고려해 이러한 현상의 원인을 알아볼 수 있다.

〈그림 15〉 개발도상국의 우울증 Root Cause 분석

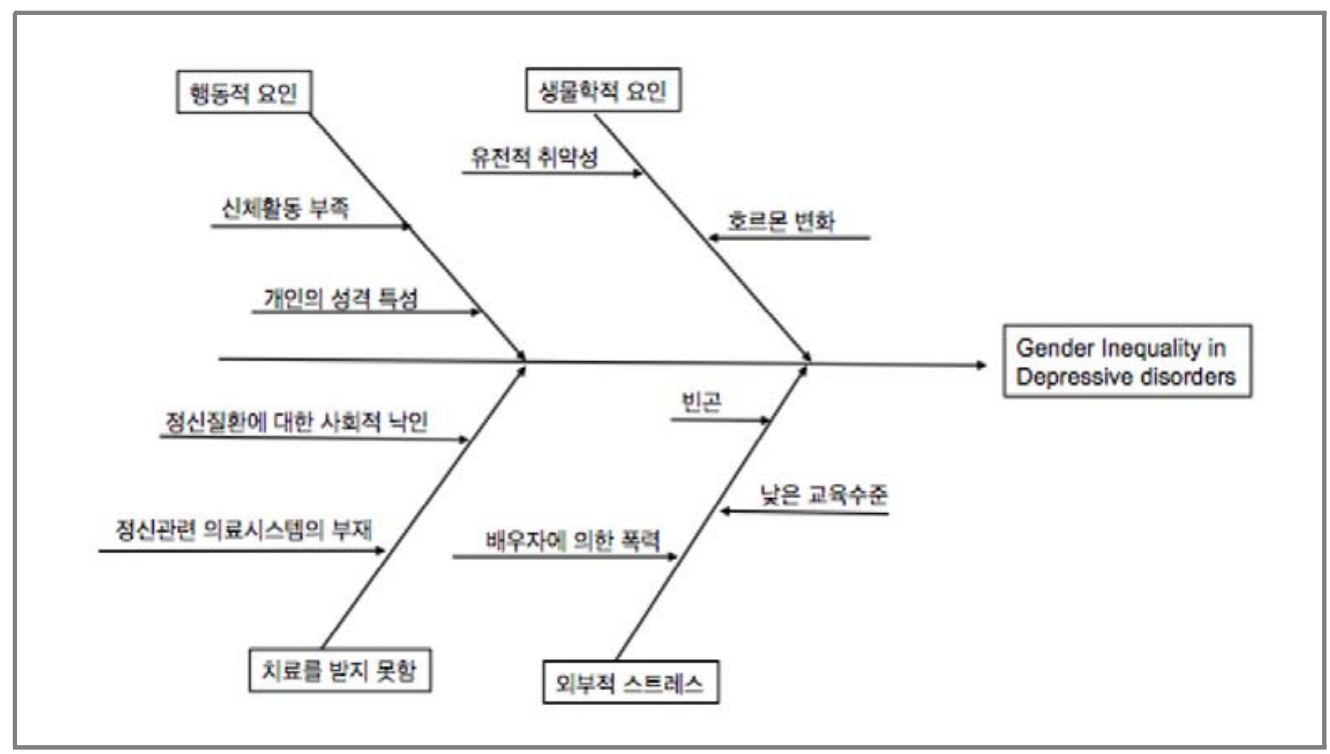

출처: 저자 작성 


\section{1) 생물학적 요인}

(1) 유전적 취약성

여성의 우울증 유병이 더 많은 이유로, 여성의 생물학적 특성이 지목된 바 있다. 이러한 특성으로, 유전적 취약성과 호르몬 변화의 요소가 설명되었다. 또한 여성의 우울증 유병이 더 높은 이유로, 염증과 우울 간의 관련성이 함께 서술된 바 있다(Derry, H. M. et al., 2015). 염증은 개인에서 우울증을 유발하는 데 중요한 역할을 하며, 우울증 또한 염증성 질환을 일으킨 다. 여성은 남성에 비해 염증 수준이 높고 또 자가면역 질환이 더 많기 때문에 여성에서 높은 우울증 유병률을 여성의 염증 취약성과 연관해 생각해 볼 수 있으며, 남성에 비해 여성은 염증으 로 유발된 기분과 행동 변화에 더 취약할 수 있다. 이를테면, 일시적으로 염증 정도가 상승했을 때 남성에 비해 여성이 외로움이나 사회적 고립을 더 많이 경험할 수 있다. 더불어 남성에 비해 높은 여성의 비만율도 염증 반응 증가와 연관되어 더 높은 우울증 유병을 보일 수 있다.

(2) 호르몬 변화

여성은 생애에서 생식 호르몬의 변화를 경험하는데, 많은 문헌에서 이런 호르몬의 변화와 우울증을 연결해 설명한다. 특히, 에스트로겐은 중앙 신경계에 많은 영향을 미치며, 이러한 영향에는 불안 및 우울반응이 포함된다(Alicia A Walf. et al., 2006). 여성의 우울증 위험은 사춘기 이후 증가되는데, 이는 에스트로겐의 순환적 변화의 시작점이기도 하며, 폐경 이후 에스 트로겐이 낮아져 많은 여성이 우울증을 경험한다.

세계적으로 여성의 수명이 증가하고 있으나, 에스트로겐의 농도가 감소하게 되는 여성의 폐경 연령이 함께 증가하는 것은 아니다. 이를 바탕으로 재고해 볼 때, 이러한 성별의 차이로 인한 문제에 대한 중재가 필요하다. 산후 우울 또한 호르몬 외의 다른 복합적인 원인들이 있지만, 출생 이후 신체에서의 급격한 호르몬(에스트로겐 및 프로게스테론)의 감소와 관련된다.

(3) 신체 활동의 부족

여성에서 신체 활동과 정신 건강 간의 양적인 관계는 여러 연구에서 밝혀진 바 있다. 신체 활동은 여성 스스로 자신의 건강 상태에 대해 느끼는 건강과 밀접하게 연관이 되어 있으며, 여성에서 낮은 신체적 활동은 우울 및 낮은 정신 건강과 연관성을 보인다(M Kull, 2002). 신체 활동의 정신적·신체적 이점이 널리 알려졌음에도 불구하고, 일반적으로 여성에서 신체 활동의 부족이 더 많이 나타난다. 이러한 이유로, 여성이 종종 가정과 돌봄 제공자로서 역할을 하며 신체 활동을 할 시간이 부족할 수 있다는 것, 여성은 특정 신체 활동에서 문화적인 이유로 
제약을 받는다는 것, 종종 남성보다 소득이 더 낮으므로 신체 활동을 할 수 있는 시설의 이용료 가 장애 요인일 수 있다는 것을 함께 생각할 수 있다.5)

(4) 빈곤

여성의 정신 건강은 사회적·정치적·경제적 문제를 떼어 놓고 해석할 수 없다. 출산이나 육아, 가정의 생계 유지, 가족의 간병 등 여성의 다양한 역할은 상당한 스트레스의 원인이 된다. 이처 럼 다양한 역할로 인해 여성은 사회적 지위나 출세, 가정 내 문제 등 다방면에서 어려움을 경험한다. 사회적 구조나 가정 내에서의 위치 등 이러한 외부적 요인들은 빈곤, 낮은 교육 수준, 낮은 사회경제적 위치, 고용시장에서의 불평등한 위치, 배우자에 의한 폭력의 모습으로 나타나 여성에게 있어 높은 우울 장애를 초래한다.

여성이 빈곤할 때, 여성의 권리는 보장받지 못하며 또 빈곤으로 인해 극복하기 어려운 여러 장애를 경험하게 된다. 남성과 여성 둘 다 빈곤을 겪는 상황 속에서 성차별이란 여성이 대처할 자원이 더 부족하다는 것을 의미한다. 빈곤 속에서 여성은 종종 가장 나중에 식사를 하고, 가족 을 간병해야 하며, 경제적 생산성이 없는 집안일에 매달려야 한다. 더불어 경제활동에 접근하는 게 어려워 약 13 억 명의 여성이 은행 및 우체국, 소액 금융기관 등 공식적인 금융기관에 계좌를 보유하고 있지 않다(WHO, 2014).

또한 여성의 경제활동이 활발한 국가에서도 성별에 따른 임금 격차로 인해 여성은 빈곤에 더 쉽게 노출된다. 미국의 경우에 2015년에 고등학교를 졸업한 여성은 같은 수준의 교육을 이수한 고졸 남성이 받는 임금의 80\% 정도를 버는 것으로 보고되었다. US Census 2014에 따르면, 석사 학위 이수자의 경우에도 여성의 임금 수준은 남성 동료가 받는 임금의 $74 \%$ 정도에 머물렀다.

개발도상국의 빈곤 여성들이 겪은 우울 및 불안 경험이 유의하게 높았다는 보고(WHO, 2013)를 재고해 볼 때, 여성의 이러한 빈곤에 따른 취약성은 여성의 높은 우울증에 기반을 둔 질병부담과 떼어서 생각할 수 없다.

(5) 낮은 교육 수준

낮은 교육 수준의 여성에서 더 많은 우울증이 관찰되는 반면, 높은 교육 수준의 여성에서는 우울증으로부터 보호 효과를 보였다(Jianguo Shi, 2014). 그러므로 여성의 교육 수준은 단순히

5) 자세한 사항은 다음 $\mathrm{WHO}$ 홈페이지에서 확인가능.

http://www.who.int/dietphysicalactivity/factsheet_women/en/(접속일: 2018.06.04.) 
일차 교육에서의 높은 입학률에 초점을 맞추기보다는 교육과정 내에서 학업을 그만두는 일이 없도록 하는 데에 초점이 맞춰져야 한다(Vikram Patel, 1999). 여성에서 일차 교육 입학률이 높더라도 대부분의 여성이 경제적 이유나 집안 가사 보조의 이유로 학업을 중단하는데, 사하라 이남 지역 아프리카 시골 지역에서 단지 $23 \%$ 의 소녀만이 일차 교육을 끝까지 유지한다(WHO, 2014). 따라서 낮은 교육 수준은 또다시 낮은 사회경제적 지위와 빈곤의 원인이 되어 우울 장애를 초래한다.

(6) 폭력

여성에 대한 폭력은 국제적으로도 만연한 문제로, 다양한 문화권에서 여성의 예방 가능한 이환율과 사망률에 상당 부분을 차지한다. 폭력은 심각한 신체적·정신적 결과를 야기하며, 여성 우울의 상당 부분을 차지한다. 추정 가능한 정도(9 28\%)의 주요 우울 장애 및 우울증상의 증가, 산후 우울증이 배우자의 폭력 경험(Intimate Partner Violence, 이하 IPV)에서 기인한 것으로 추정된다(Hind A., 2012). IPV는 개발도상국이나 선진국에서 모두 남성에 비해 여성에 게 더 일어나며, 우울뿐만 아니라 만성 통증이나 기타 질병에도 취약하게 한다.

(7) 정신 질환에 대한 사회적 낙인

많은 여성이 우울증으로 어려움을 경험하고 있다. 그럼에도 불구하고 우울증을 비롯한 정신 질환을 치료하며 초래될 사회적 낙인이 두려워 정신적 질환에 대한 치료 및 지지는 부족하다. 여성은 다양한 방식으로 낙인을 경험하는데, 여성이 우울증이 있을 때 그들은 사회에서 선호하 는 가치인 생산적이고, 능력 있으며, 활기찬 모습과 멀어지게 된다. 여성들은 그들의 우울증에 대해 내적으로 수치감을 느끼며 또 그들 스스로 정상이 아니라고 말한다(Rita Schreiber, 2009). 이러한 수치감으로 인해 여성에게 낙인이 찍히는 것이며, 여성은 이러한 낙인을 경험하 게 된다.

(8) 개인의 성격 특성

여성에서 우울증이 많이 발생하는 이유를 여성의 성격 특성과 관련지어 원인을 탐구하고자 하는 연구가 이루어진 바 있다(Altman, 1980). 개인의 성격은 유전적이고 또 타고나는 기질과 환경의 상호작용을 통해 형성되는, 개인이 갖고 있는 독특하고 일관된 행동 양식으로 정의할 수 있다. 성격은 사회·문화적 학습의 영향을 받아 일생 동안 발달·성숙하면서 기질에 의한 자동적 정서 반응을 조절해 자극에 대한 최종 반응을 결정한다(Klein, 2011).

신경증적 특성이나 위험을 회피하려는 성격적인 특성이 우울증과 연관되어 있다는 발견 
(Kenneth S. Kendler, 1993)과 여성이 남성보다 우울증을 많이 경험한다는 연구 보고가 있으 나, 여성의 특정 성격이 우울증을 야기한다는 연구 결과는 찾을 수 없었다. 즉, 통념상 여성으로 서의 어떠한 성격적 특성이 여성의 높은 우울 장애 질병부담과 관련될 것이라고 여기지만, 세계적으로 볼 때 여성이 남성에 비해 우울과 높은 연관성을 가진 어떠한 성격적 특성이 있는지 는 알려지지 않고 있다. 따라서 통념과 달리, 여성의 성격적 특성을 우울증의 원인으로 보기에는 증거가 충분하지 않다.

(9) 의료 시스템

개발도상국가에서 많은 원조가 여성의 생식 건강 및 모자보건에 초점이 맞추어져 있으며, 이는 여성의 정신 건강적인 필요를 고려하고 있지 않다. 원조가 이루어지는 개발도상국에서 여성은 병원의 역할을 출산과 연결함으로써 출산을 제외한 자신의 건강 문제로 병원을 방문하는 것을 익숙하지 않아 하며, 자신의 정신 건강 문제를 병원에서 치료해야 한다는 필요성을 인식하 지 못한다. 더불어 여성의 생식 건강에 초점이 맞춰진 것에 반해, 중·저소득 국가에서 여성의 산후 우울에 관한 자료는 부족한 실정이다. 


\section{III. 윤리적 이슈(Ethical Issue)}

\section{1. 질병별 접근}

제I장

\section{제II장}

1) $H I V$ 를 제외한 성매개질환

위와 같이 살펴볼 때, 개발도상국 내 여성의 사회경제적 지위, 성별 권력 관계의 불균형 문제 등으로 인해 여성은 전반적인 보건의료 서비스에 대한 접근이 제한적이다. 또한 주체적인 인간으로서 존중받지 못하는 문화 속에서 가정 내 폭력 등에 노출되어 있고, 안전한 성관계나 콘돔 사용을 요구할 수 없는 상황에 처해 있다. 아울러 저소득 국가의 경우에는 성매개질환 검진이나 치료 서비스 제공 시 환자에 대한 개인정보 보호 체계가 탄탄하게 마련되어 있지 않다. 그러다 보니 취약 계층에 속하는 여성들은 사회적 낙인 등으로부터 스스로 방어하기 위해 치료를 중단해 버리거나, 시설 방문 자체를 꺼리는 경우가 흔히 발생한다.

이러한 제약들은 인권과 성 평등의 관점에서 궁극적으로 해결되어야 하는 문제이며, 지역사 회 차원에서 점차 인식을 개선해 나감과 동시에 옹호 활동 등의 노력을 통해 실질적인 정책적 뒷받침도 함께 추구해야 할 것이다. 그러나 각 지역마다 가지고 있는 고유한 문화와 관습이 크게 침해되지 않는 선에서, 주민들과의 동의와 협의 과정을 통해 장기적인 노력으로 점진적인 변화를 이끌어 내야 할 것이다.

한편, 의료 인력들은 성매개질환과 관련된 서비스를 제공할 때, 위험 부담이 높은 행동을 줄이고자 전통적이고 불평등한 성 역할을 강화하는 접근 방식을 통해 성 관련 낙인이 영속화하 지 않도록 유의해야 할 필요가 있다. 이러한 윤리적 고려는 의도치 않은 손해나 결과들을 최소화 하기 위함이며, 보건의료 서비스의 혜택에 대한 평등한 접근성을 제공함으로써 여성들이 본인의 성 건강을 주도적으로 책임질 수 있도록 해, 궁극적으로는 여성의 주체성과 역량을 강화하고 또 사회 정의를 실현하기 위함이다(Semanna et al., 2007).

\section{2) 알츠하이머}

노인 여성의 경우에는 치매로 인한 질병부담이 높으며, 보건에 대한 필요는 높으나 이에 대한 대처는 미비하다(Prince, 2015). 특히 개발도상국에서 치매는 노화의 과정이면서 뇌 질환 즉, 질병이라는 것을 가족 구성원에게 설득하는 것이 어려울 수 있다. 개발도상국에서 환자가 치매 치료를 통한 혜택을 입을 가능성이 있다면, 치매 사실을 환자에게 알려야 한다. 하지만 
혜택의 가능성이 없거나, 치매 사실의 공개가 오히려 불리한 반응(가족 구성원에 대한 사회적 낙인 등)을 일으키기 쉬운 상황에서 이를 공개하는 것은 권고되지 않는다(Maestre, 2012). 또한 치매는 당사자뿐만 아니라 보호자 및 가족과 사회에 미치는 부담이 크다. 보호자의 경우에 는 대부분 같은 여성이므로, 여성의 질병부담뿐만 아니라 보호자로서 여성의 부담이 증가하기 때문이다.

\section{3) 우울증}

여성의 우울에서 인식과 치료는 문화 속에서 여성의 다양한 역할 및 빈곤의 덫과 연결되어 여러 어려움을 겪는다. 윤리적으로 사람은 누구나 자율성에 따라 자신의 치료를 결정할 수 있으나, 많은 문화권에서 우울증 치료의 자율성은 여성 개인의 선택이기보다는 집의 경제권을 담당하는 남성의 결정에 따르게 된다. 여성이 자신의 치료에 대한 권한이 있더라도 가사 부담이 나 육아, 간병 등 다양한 역할을 수행하며 우울증을 인정하고 치료하는 시기가 늦어지고 있다. 특히, 정신 질환이라는 사회적인 낙인이 우려되어 우울증 치료는 더욱 미루어지고 있다.

앞서 여성의 빈곤 및 낮은 교육 수준이 우울과 연관이 있다고 밝힌 바 있다. 그러므로 빈곤의 덫 속에서 여성의 빈곤, 낮은 교육 수준, 낮은 사회경제적 지위가 또다시 빈곤과 연결되어 우울 과 강한 연관성을 갖는다는 것을 생각해 볼 수 있다. 우울을 여성의 자율적인 치료 의지에 따라 달라질 수 있는 질병으로 볼 수 있는지, 강한 의문점이 들게 된다.

많은 문화권에서 여성에게 다양한 역할을 기대하며, 기대되는 역할의 수행과 불평등한 사회 구조로 인해 사회경제적 지위가 낮은 여성은 우울의 위험에 더 많이 노출되며 또 빈곤의 덫 속에서 그러한 위험은 계속된다. 또한 사회경제적 지위와 상관없이 우울은 여성에게서 질병부담 이 높지만, 세계적으로 우울증은 정신 질환에 대한 낙인과 치료 시설이 부족한 탓에 여성은 우울에서 높은 질병부담을 갖고 있다. 이러한 면에서 여성의 우울증에 따른 질병부담이 지속되 고 또 악화되는 불평등의 모습을 확인할 수 있으며, 이러한 여성의 불평등은 국제적인 윤리적 문제 중 하나다.

\section{2. 연구 수행 과정에서의 접근}

WHO의 Scientific and Ethical Review Group(성생식보건 분야)에 따르면, 중재 (intervention)나 연구(research)가 기존의 성 불평등을 악화시키지 않도록 해야 하고, 보다 이상적으로는 중재와 연구가 가능한 젠더불평등 감소에 기여해야 함을 강조하고 있다. 연구 
의 주제 측면에서는 남성과 여성 및 남성 혹은 여성이 필요로 하는(필요하다고 표현하는) 요구(needs)에 잘 접근하고 있는지 살펴볼 필요가 있다고 제시하고 있다. 또한 연구 과정 측면에서는 연구로 도출된 결과를 공유할 때, 성생식보건 분야의 경우일지라도 해당 커뮤니 티의 여성뿐 아니라 남성과도 공유해야 하고 또 연구팀의 성별 구성도 고려할 것을 권고하고 있다. 


\title{
IV. 문제 해결을 위한 제안(Problem Solving)
}

여성의 건강불평등을 해결하기 위해서는 다각적인 측면의 접근이 필요하며, 동시에 질병별 특성을 반영한 고려도 필요하다. 그 중에서 우선 성 주류화에 대한 모니터링 강화는 필수적이다. 성 주류화(Gender mainstreaming)를 아래와 같이 정의할 수 있다.

\section{〈상자 1〉 성 주류화의 정의}

\begin{abstract}
"모든 분야와 모든 수준에서 입법이나 정책 또는 프로그램을 포함해 계획된 행동에 대해 여성과 남성의 함의를 평가하는 과정이다. 이는 여성과 남성의 관심사와 경험을 모든 정치적 - 경제적 - 사회적 분야의 정책과 프로그램의 설계·구현 · 모니터링 및 평가의 필수적인 차원으로 만들기 위한 전략이다. 이는 여성 과 남성이 동등하게 혜택을 받고 또 불평등이 계속되지 않도록 하기 위함이며, 궁극적인 목적은 남녀평등을 성취하는 것이다."

"성 주류화는 1995년 베이징여성대회에서 주요한 글로벌 차원의 전략으로 채택된 이래, 남성과 여성의 건강 증진을 위해 필요한 접근이었다. 하지만, 여전히 건강에 있어 성 불평등은 존재한다. 따라서 성 주류화 를 기반으로 한 국제사회와 국가 차원의 노력은 계속 필요하다."
\end{abstract}

출처: UN (2002)

선언만이 아닌, 실질적인 이행을 위해 국제사회는 성 주류화 모니터링 기능을 강화한 후 국가들이 건강에 있어서 성 주류화를 더욱 높은 우선순위에 둘 수 있도록 하는 노력이 필요하다. 또한 국가 차원에서는 건강과 연계된 모든 정책과 프로그램을 설계·구현·모니터링할 때, 체계적 인 성 분석과 남녀 간 권력 균형 및 자원 분배 문제를 고려해야 한다.

〈표 3〉 글로벌 · 국가 차원의 문제 해결 제안

\begin{tabular}{|c|c|c|}
\hline 구분 & 글로벌 차원의 접근 & 국가 차원의 접근 \\
\hline 여성건강불평등 & $\begin{array}{l}\text { - Gender mainstreaming 모니터링, } \\
\text { 여성임파워먼트 강조 }\end{array}$ & - 국가 정책에의 Gender mainstreaming \\
\hline $\begin{array}{l}\mathrm{HIV} \text { 를 제외한 성 } \\
\text { 매개질환 }\end{array}$ & - 글로벌 성매개질환 감시 체계 강화 & $\begin{array}{l}\text { - 현지 문화와 관습, 특히 여성에 대한 사회적 인식 } \\
\text { 을 고려한 성매개질환 예방 및 치료 전략 수립 } \\
\text { - 인식 개선을 통한 성매개질환 검진 장려, 환자 } \\
\text { 확인 및 치료 서비스 제공 } \\
\text { - 콘돔 사용 등에 대한 캠페인, social marketing } \\
\text { 등 진행 } \\
\text { - 여성 평등에 대한 주민 교육, 여성 자립 역량 향상 } \\
\text { 을 위한 소득 창출 지원 등 }\end{array}$ \\
\hline 알츠하이머 & $\begin{array}{l}\text { - 생애 주기별 질병부담에 따른 보건 } \\
\text { 서비스 제공에 대한 가이드라인 제 } \\
\text { 공 }\end{array}$ & $\begin{array}{l}\text { • 치매 조기 진단 } \\
\text { - 치매에 대한 인식 증진 } \\
\text { • 여성 교육률 향상 } \\
\text { - 여성의 사회적 활동을 위한 기반 }\end{array}$ \\
\hline
\end{tabular}




\begin{tabular}{|c|c|c|}
\hline 구분 & 글로벌 차원의 접근 & 국가 차원의 접근 \\
\hline 우울증 & $\begin{array}{l}\text { - 우울증에 대한 관심을 높일 수 있 } \\
\text { 는 } 2017 \text { 년 WHO의 "Depression, } \\
\text { let's talk"와 같은 캠페인을 수행하 } \\
\text { 고, 우울증에 대한 인식을 제고 }\end{array}$ & $\begin{array}{l}\text { - 성별의 다름(differences in sex)을 고려 } \\
\text { - 여성의 교율류 향상 } \\
\text { - 여성의 우울증을 부끄러운 것이 아니며, 생물학 } \\
\text { 적 혁상의 하나로 인식해야 함 } \\
\text { - 여성에게 우울증을 예방할 수 있는 다양한 중재 } \\
\text { 방안(예, 신체 활동 시설에 접근성을 높이거나 금 } \\
\text { 전적인 지원)을 마련 }\end{array}$ \\
\hline
\end{tabular}

출처: 저자 작성

또한 본고에서 다룬 세부 질병(HIV를 제외한 성매개질환, 알츠하이머, 우울증)에서 나타나 는 여성의 건강불평등을 해결하기 위해 글로벌 차원에서의 접근과 해당 국가 차원의 접근을 위 <표 3>과 같이 구분해 생각할 수 있다.

본고에서 개발도상국 여성의 건강불평등 현황 및 그 원인을 살펴보았으며, 이러한 문제를 해결하기 위해서는 성 주류화 등 글로벌 차원의 노력뿐만 아니라, 해당 질병별로 국가 차원의 노력도 병행되어야 한다. 


\section{참고 문헌}

Alicia A walf, Cheryl A Frye. 2006. "A Review and Update of Mechanisms of Estrogen in the Hippocampus and Amygdala for Anxiety and Depression Behavior." Neuropsychopharmacology vol.31: 1097-1111.

Amartya Sen. 2003. "Missing women-revisited, Reduction in female mortality has been counterbalanced by sex selective abortions." British Medical Journal vol.327(7427): 1297-1297.

Aparna Mitra. 2015. "Son Preference in India: Implications for Gender Development." Journal of Economic Issues vol.48: 1021-1037.

CDC. 2011a. "10 Ways STDs Impact Women Differently from Men." Atlanta: Center for Disease Control and Prevention (CDC), available at https:// www.cdc.gov/std/health-disparities/stds-women-042011.pdf (접속일: 2018.06.30.).

. 2011b. "Centers for Disease Control and Prevention, National Center for HIV Viral Hepatitis STD and TB Prevention." Atlanta: Center for Disease Control and Prevention (CDC).

Cecilia Leonardo and Joan C. Chrisler. 1992. "Women and sexually transmitted diseases." Women Health vol.18(4): 1-15.

Dohrenwend BP, Levav I, Shrout PE, Schwartz S, Naveh G, Link BG, Skodol AE, Stueve A. 1992. "Socioeconomic status and psychiatric disorders: the causation-selection issue." Science vol.255(5047): 946-52.

Ezzati M, Lopez A, Rodgers A, Murray C. 2004. "Comparative quantification of health risks: global and regional burden of disease attributable to selected major risk factors." Geneva: World Health Organization (WHO), available at http://apps.who.int/iris/handle/10665/42770 (접속일: 2018.06.30.).

Gita Sen and Piroska Östlin. 2007. "Unequal, Unfair, Ineffective and Inefficient Gender Inequity in Health: Why it exists and how we can change it." Final Report to the WHO Commission on Social Determinants of Health. Geneva: World Health Organization (WHO).

Gladys E. Maestre. 2012. "Assessing dementia in resource-poor regions." Current neurology and neuroscience reports vol.12(5), 511-519. 
Go VF, Quan VM, Chung A, Zenilman J, Hanh VT, Celentano D. 2002. "Gender gaps, gender traps: sexual identity and vulnerability to sexually transmitted diseases among women in Vietnam." Social Science \& Medicine vol.55(3): 467-481.

Heather M. DerryAvelina C. PadinJennifer L. KuoSpenser HughesJanice K. Kiecolt-Glaser. 2015. "Sex Differences in Depression: Does Inflammation Play a Role?" Current Psychiatry Reports vol.17(10).

Kalaria RN1, Maestre GE, Arizaga R, Friedland RP, Galasko D, Hall K, Luchsinger JA, Ogunniyi A, Perry EK, Potocnik F, Prince M, Stewart R, Wimo A, Zhang ZX, Antuono P. 2008. “Alzheimer's disease and vascular dementia in developing countries: prevalence, management, and risk factors." Lancet Neurol vol.7(9):812-826.

Kendler KS, Neale MC, Kessler RC, Heath AC, Eaves LJ. 1993. “A Longitudinal Twin Study of Personality and Major Depression in Women." Arch Gen Psychiatry. vol.50(11):853-862.

Mayaud P, Mabey D. 2004. "Approaches to the control of sexually transmitted infections in developing countries: Old problems and modern challenges." Sexually Transmitted Infections vol.80(3):174-182.

Prince M J. 2015. “World Alzheimer Report 2015: the global impact of dementia: an analysis of prevalence, incidence, cost and trends." London: Alzheimer's Disease International, available at https://www.alz.co.uk/research/worldreport-2015 (접속일: 2018.06.15.)

Rachel Mash. 2010. "Why don't you just use a condom?: Understanding the motivational tensions in the minds of South African women." African Journal of Primary health care \& Family medicine. vol2(1):1-4.

M Kull. 2002. "The relationships between physical activity, health status and psychological well being of fertility aged women.” Scandinavian Journal of Medicione \& Science in Sports vol.12(4), 241-247.

Rebecca J. Cabral, LeaVonne PulleyLynn M ArtzIlene BrillMaurizio Macaluso. 1998. "Women at Risk of HIV/STD: The Importance of Male Partners as Barriers to Condom Use." AIDS and Behavior vol(2): 75-85.

Rita Schreiber and Gwen Hartrick. 2009. “Keeping it together : How women 
use the biomedical explanatory model to manage the stigma of depression." Issues in Mental Health Nursing vol.23(2): 91-105.

Patel V, Araya R, de Lima M, Ludermir A, Todd C. 1999. "Women, poverty and common mental disorders in four restructuring societies." Social Science \& Medicine vol.49:1461-1471.

Shi J, Zhang Y, Liu F. 2014. "Associations of Educational Attainment, Occupation, Social Class and Major Depressive Disorder among Han Chinese Women.” PLoS ONE vol.9(1).

Semaan S, Leinhos M. 2007. "The Ethics of Public Health Practice for the Prevention and Control of STDs" Behavioral Interventions for Prevention and Control of Sexually Transmitted Disease. Boston: Springer: 517-548.

Serren Thaddeus, Deborah Maine. 2014. "Too far too walk: maternal mortality in context." Social Science \& Medicine vol(38):1091-1110.

Tilly Eichler, Jochen René Thyrian, Johannes Hertel, Bernhard Michalowsky, Diana Wucherer, Adina Dreier, Ingo Kilimann, Stefan Teipel, Wolfgang Hoffmanna. 2015. "Rates of formal diagnosis of dementia in primary care: The effect of screening." Alzheimers Dement (Amst) vol.1(1): 87-93.

Tim Slade, Cath Chapman, Wendy Swift, Katherine Keyes, Zoe Tonks, Maree Teesson. 2016. "Birth cohort trends in the global epidemiology of alcohol use and alcohol-related harms in men and women: systematic review and metaregression.” BMJ Open vol.6(10).

Todd M. Derreberry, Suzanne Holroyd. 2017. "Dementia in Women.” Psychiatric clinics vol.40: 299-307.

UNAIDS. 1998. "The public health approach to STD control: UNAIDS technical update." Geneva: The Joint United Nations Programme on HIV/AIDS (UNAIDS).

US Census Bureau. 2014. "Comparing 2014 American Community Survey Data," Maryland: United States Census Bureau.

UN. 2002. "Gender Mainstreaming: An Overview." New York: United Nations, available at http://www.un.org/womenwatch/osagi/pdf/e65237.pdf (접속일: 2018.05.05.) 
UN Women. "Women and Poverty." New York: UN Women, available at http://beijing20. unwomen.org/en/in-focus/poverty (접속일: 2018.06.04.).

Van den Dungen P, van Marwijk HW, van der Horst HE, Moll van Charante EP, Macneil Vroomen J, van de Ven PM, van Hout HP. 2012. “The accuracy of family physicians' dementia diagnoses at different stages of dementia: a systematic review." International Journal of Geriatric Psychiatry vol.27(4):342-354.

WHO. 2001. "Global prevalence and incidence of selected curable sexually transmitted infections: overviews and estimates." Geneva: World Health Organization (WHO), available at http://www.who.int/reproductivehealth/ publications/rtis/HIV_AIDS_2001_2/en/ (접속일: 2018.07.04.)

WHO. 2005. "Overview on women's health in crises." Health in emergencies. Geneva: World Health Organization (WHO).

WHO. 2014. "World health statistics 2014." Geneva: World Health Organization (WHO), available http://www.who.int/gho/publications/world_health_statistics/ 2014/en/ (접속일: 2018.06.01.).

World Bank. 1993. "World development report 1993: investing in health." Washington D.C.: World Bank, available at https://openknowledge.worldbank.org/ handle/10986/5976 (접속일: 2018.06.01.).

WHO. "Sexual and reproductive health: Ethical issues" posted on WHO official homepage, available at http://www.who.int/reproductivehealth/topics/ethics/ gender_guide_serg/en/ (접속일: 2018.06.01.).

WHO. "Physical Activity and Women" posted on WHO official homepage, vailable at http://www.who.int/dietphysicalactivity/factsheet_women/en/ (접속일: 2018.06.04.). 